\title{
Steam System Balancing and Tuning for Multifamily Residential Buildings in Chicagoland
}

Jayne Choi, Peter Ludwig, and Larry Brand Partnership for Advanced Residential Retrofit 


\begin{abstract}
NOTICE
This report was prepared as an account of work sponsored by an agency of the United States government. Neither the United States government nor any agency thereof, nor any of their employees, subcontractors or affiliated partners makes any warranty, express or implied, or assumes any legal liability or responsibility for the accuracy, completeness, or usefulness of any information, apparatus, product, or process disclosed, or represents that its use would not infringe privately owned rights. Reference herein to any specific commercial product, process, or service by trade name, trademark, manufacturer, or otherwise does not necessarily constitute or imply its endorsement, recommendation, or favoring by the United States government or any agency thereof. The views and opinions of authors expressed herein do not necessarily state or reflect those of the United States government or any agency thereof.
\end{abstract}

Available electronically at http://www.osti.gov/bridge

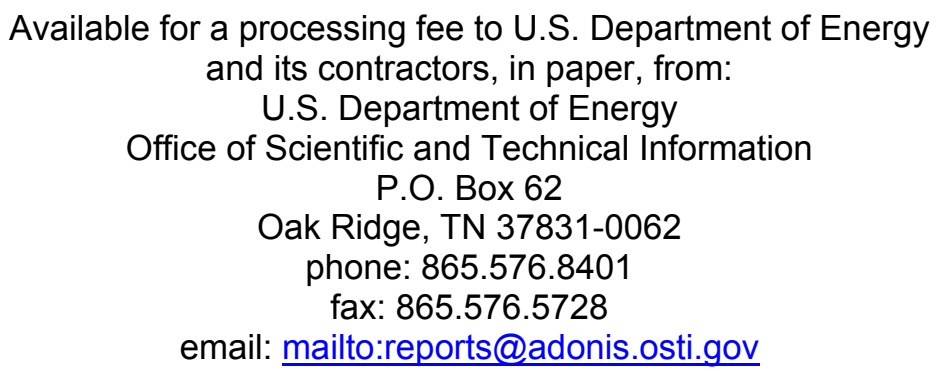

Available for sale to the public, in paper, from:

U.S. Department of Commerce

National Technical Information Service

5285 Port Royal Road

Springfield, VA 22161

phone: 800.553 .6847

fax: 703.605 .6900

email: orders@ntis.fedworld.gov

online ordering: http://www.ntis.gov/ordering.htm

Printed on paper containing at least $50 \%$ wastepaper, including $20 \%$ postconsumer waste 


\title{
Steam Balancing and Tuning for Multifamily Residential Buildings in Chicagoland
}

\author{
Prepared for: \\ Building America \\ Building Technologies Program \\ Office of Energy Efficiency and Renewable Energy \\ U.S. Department of Energy \\ Prepared by: \\ Jayne Choi, Peter Ludwig, Larry Brand \\ Partnership for Advanced Residential Retrofit \\ Gas Technology Institute Contract 21138 TO2 Deliverable 7.1.3 \\ CNT Energy \\ 2125 W North Avenue \\ Chicago, IL 60647 \\ NREL Technical Monitor: Stacey Rothgeb \\ Prepared Under Subcontract No. KNDJ-0-40346-00
}

August 2012 
[This page left blank] 


\section{Contents}

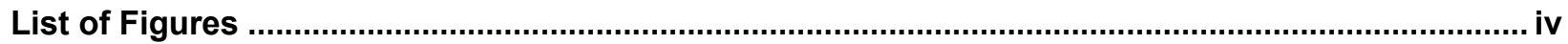

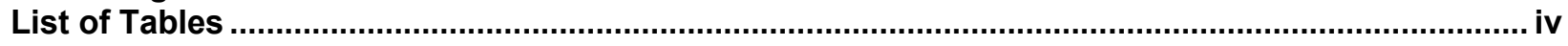

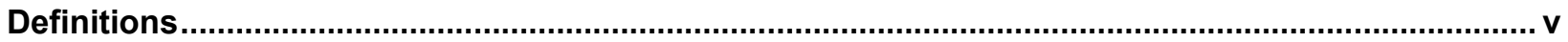

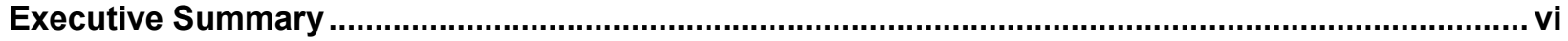

1 Problem Statement

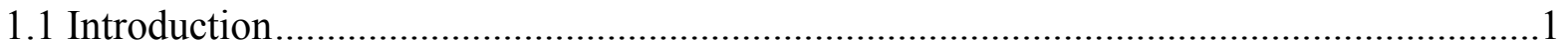

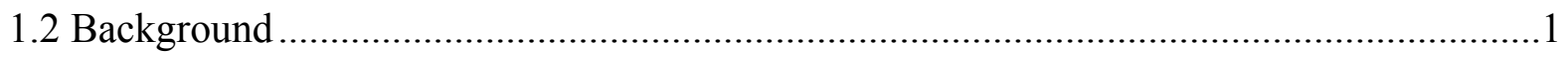

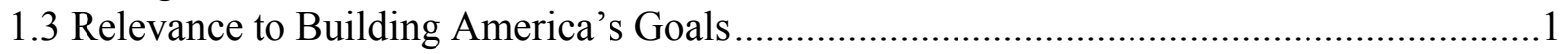

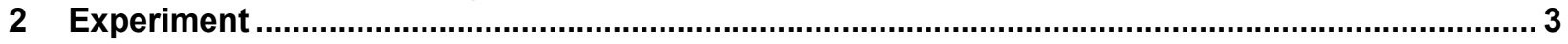

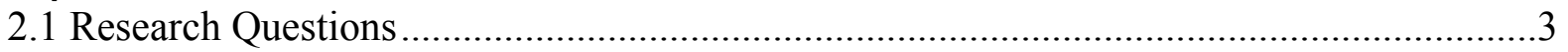

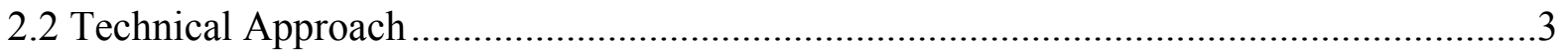

2.3 Assessment of One-Pipe Steam Heating Systems: What To Look For ............................4

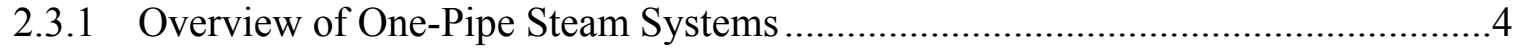

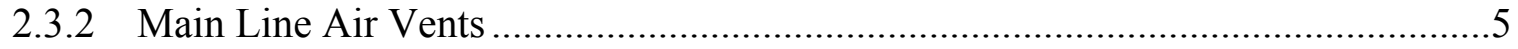

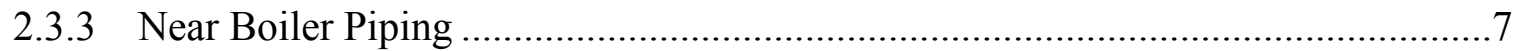

2.3.4 Boiler Controls ......................................................................................

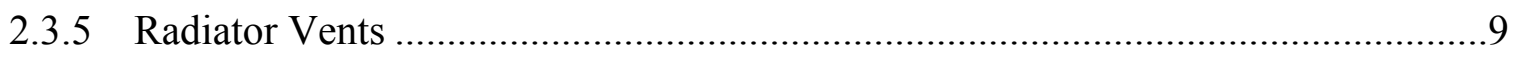

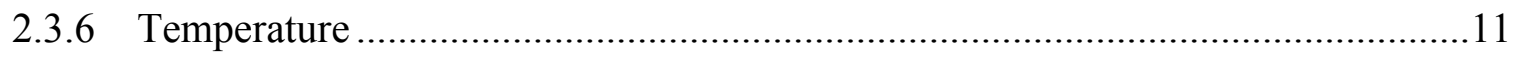

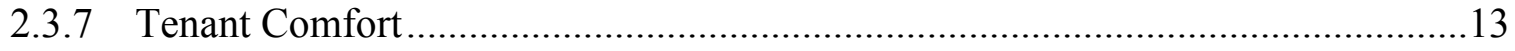

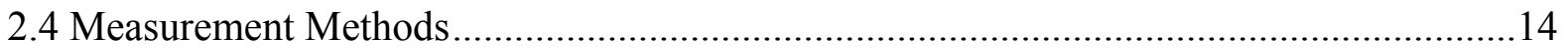

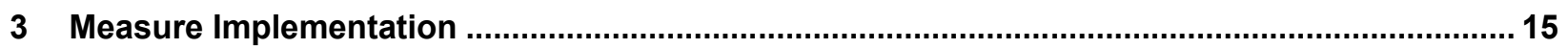

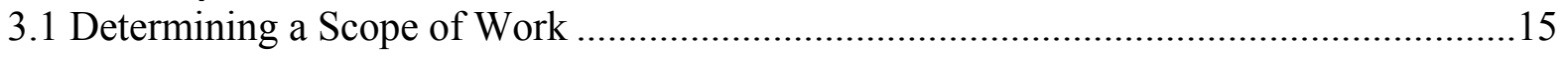

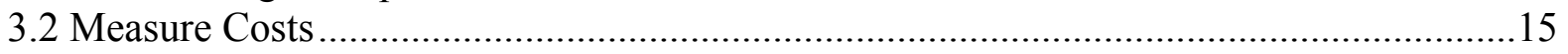

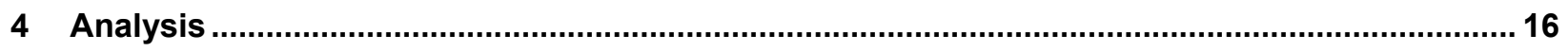

4.1 Temperature Control and Steam System Behavior................................................ 16

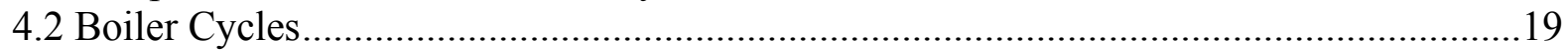

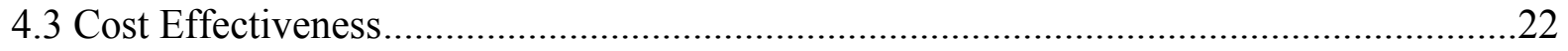

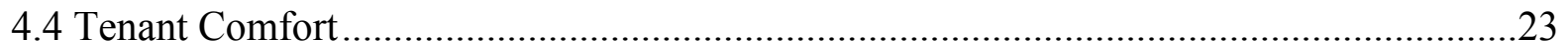

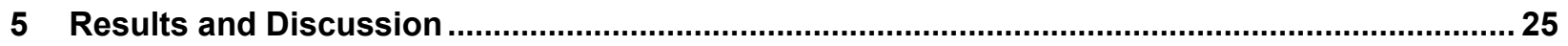

5.1 Temperature Control and Steam Systems Behavior ...............................................25

5.2 Cost Effectiveness..............................................................................................26

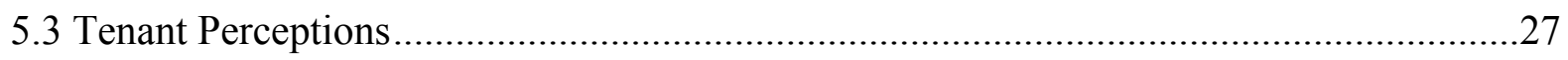

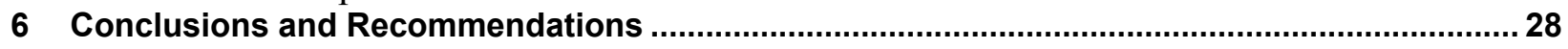

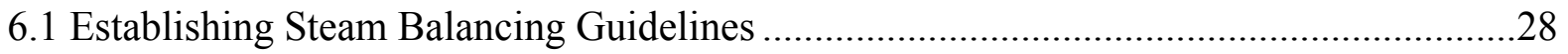

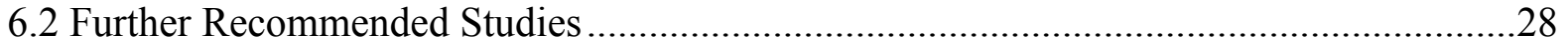

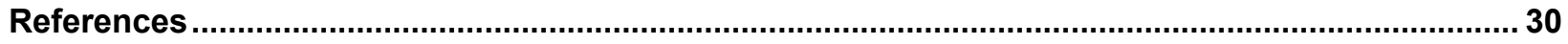

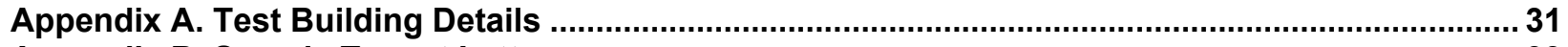

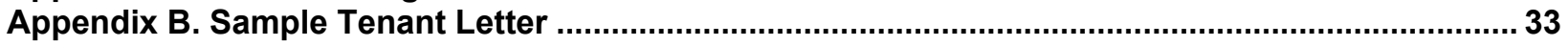

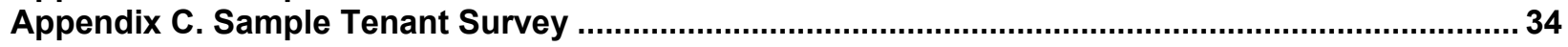

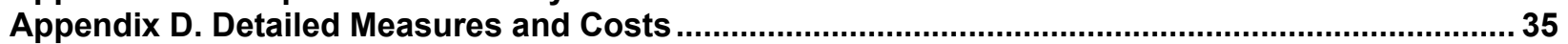




\section{List of Figures}

Figure 1. Two of 10 test buildings. 4

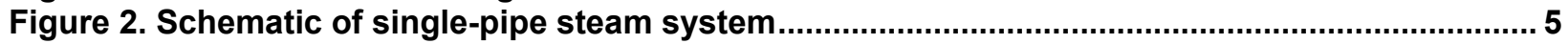

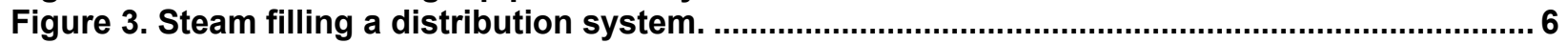

Figure 4. Insufficiently sized header piping. ............................................................................ 7

Figure 5. Specifications for how to pipe a Series 211A natural gas steam boiler by Peerless .......... 8

Figure 6. Gorton No. 4 angle radiator vent ................................................................................ 10

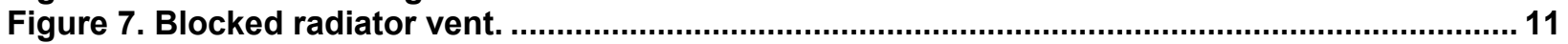

Figure 8. Schematic plan of a building in the study with logger placements................................... 13

Figure 9. Building 5 average pre-measure logging period temperature readings .............................17

Figure 10. Building 5 average post-measure logging period temperature readings ........................ 17

Figure 11. Building 4 average pre-measure logging period temperature readings .......................... 18

Figure 12. Building 4 average post-measure logging period temperature readings ...................... 18

Figure 13. Weather-normalized calculated natural gas use pre-balancing and post-balancing ...... 21

Figure 14. Tenant survey responses rating overall temperature comfort .........................................2 24

Figure 15. Building 3 average pre-measure logging period temperature readings ...........................26

Figure 16. Building 3 average post-measure logging period temperature readings ........................ 26

Unless otherwise indicated, all figures were created by PARR.

\section{List of Tables}

Table 1. Logger Equipment

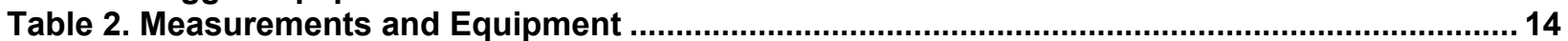

Table 3. Average Costs for Common Steam Balancing Measures ................................................... 15

Table 4. Cycle Counts per Year, Average Lengths of Boiler Cycles and Percent of Day Boiler On 20

Table 5. Calculated Weather-Normalized Natural Gas Use................................................................ 22

Table 6. Measured Weather-Normalized Natural Gas Use ........................................................... 23

Unless otherwise indicated, all tables were created by PARR. 


\title{
Definitions
}

\author{
AFUE Annual fuel utilization efficiency \\ ASHRAE American Society of Heating, Refrigerating and Air-Conditioning Engineers \\ Btu British thermal unit \\ CDD Cooling degree days \\ CNT Center for Neighborhood Technology \\ DOE U.S. Department of Energy \\ EUI Energy use intensity \\ HDD Heating degree days \\ NBP Near boiler piping
}




\section{Executive Summary}

Chicago's older multifamily housing stock is primarily heated by centrally metered steam or hydronic systems, and the cost of heat for tenants is typically absorbed into the owner's operating costs. Highly variable and rising energy costs have placed a heavy burden on landlords. In the absence of well-designed and relevant efficiency efforts, increased operating costs would be passed on to tenants who often cannot afford those increases.

Misinvestment is a common problem with older heating systems - multiple contractors may inadequately or inappropriately upgrade parts of systems and reduce system functionality and efficiency, or the system has not been properly maintained. The primary reasons for the lack of proper investment in the steam heated multifamily building stock are:

- There is a tendency to defer maintenance in the absence of capital funds.

- Knowledge about available technologies may be lacking.

- Appropriate contractor solutions may be lacking.

- The benefits and definition of system balancing may be nontransparent or unclear.

System balancing may be one of the most cost-effective efficiency opportunities available. However, it is not well-defined in the market, largely because it does not necessarily involve the purchase of tangible equipment and assets. The associated comfort improvements, utility cost savings, and contractor methodologies are thus rarely well documented in the marketplace.

This report addresses these barriers to information, contractor resources, and cost savings. Building on previous research, CNT Energy identified 10 test buildings and conducted a study to identify best practices for the methodology, typical costs, and energy savings associated with steam system balancing. A package of common steam balancing measures was assembled and data were collected on the buildings before and after these retrofits were installed to provide building owners, contractors, and utility companies a clear and concise understanding of the process, challenges, and the cost effectiveness of steam system balancing. Results reveal that on average, steam balancing measures will save approximately $14.2 \%$ of the natural gas used for heating and improve tenant comfort. The methodologies for and findings from this study are presented in detail in this report.

\section{Acknowledgment}

PARR acknowledges the U.S. Department of Energy Building America Program for its funding and support in developing this technical report. CNT Energy would like to thank the building owners and tenants involved in this study for their participation, and Scott Fewer of Fewer Boilers, Inc., for his time, technical assistance, and expertise. 


\section{Problem Statement}

\subsection{Introduction}

Old steam systems in multifamily residential buildings invariably suffer from imbalance: some apartments are too hot and some are too cold. Providing a balanced building, where heat reaches all the apartments in a timely fashion, minimizes wasted heating fuel and is therefore an opportunity for great cost savings. Additionally, a balanced building improves tenant comfort. However, the process is sometimes unclear, so contractors typically do not sell steam system balancing as a service and owners do not buy it. The information provided by this study explores whether steam balancing could be an efficiency measure that building owners and utility companies can implement as a cost-effective and long-lasting retrofit.

\subsection{Background}

Previous research performed by the Minneapolis Energy Office, the Center for Neighborhood Technology (CNT) in Chicago, and New York State Energy Research and Development Authority in New York City documented techniques and savings associated with steam balancing and laid the groundwork for this research. The research showed that venting and controlling the steam cycle are particularly important for steam balancing, which was taken into consideration when measures were selected and assessments were done for this study (Peterson 1986; Biederman and Katrakis 1989).

Previous studies have also shown that ensuring tenant awareness in advance of and during the project increase its success and facilitate a smoother experiment (Biederman et al. 1989). This project took this into consideration as a part of its technical approach.

Although the costs and savings associated with steam balancing will vary depending on measures administered to the particular subjects in a building sample, previous studies have shown it to be a cost-effective measure. Energy savings of 5\%-15\% with a range of paybacks of $2-5$ years have been reported. Frequently, paybacks were less than one year (Katrakis, Lobenstein, and Hewett 2010).

\subsection{Relevance to Building America's Goals}

The U.S. Department of Energy's (DOE) Building America program is designed to "reduce the home energy use by 30-50\% (compared to 2009 energy codes for new homes and pre-retrofit energy use for existing homes)." To this end, the program looks to conduct research to "develop market-ready energy solutions that improve efficiency of new and existing homes in each U.S. climate zone, while increasing comfort, safety, and durability" (DOE 2011).

This steam balancing project was directed primarily to multifamily residential buildings in Chicagoland. As a colder humid continental climate, Chicago has an average of 6,500 heating degree days (HDDs) and 800 cooling degree days (CDDs) per year; heating is therefore the focus of residential energy use. Of the 16.7 million multifamily housing units nationwide - defined as five or more units - 2.5 million are steam heated. In the 470,000 multifamily units in the Chicagoland region, it has been estimated that at least 70,000 of those units are steam heated. Using a conservative estimate of 100 therms saved per unit annually, approximately 7 million therms might be saved in the Chicagoland area, and approximately 250 million therms nationwide. At $\$ 1 /$ therm, $\$ 7$ million might be saved in Chicagoland and \$250 million 
nationwide. By these estimates, the relevance of improving steam heating to the DOE's Building America goals is clear. Streamlining steam balancing and increasing its visibility will contribute an effective energy solution to the marketplace. 


\section{Experiment}

\subsection{Research Questions}

- How do steam balancing measures affect the temperature dynamics between units?

- Will steam balancing affect the average length and frequency of boiler cycles?

- How will steam balancing affect the amount of natural gas used for heating?

- How cost effective are steam balancing measures?

- What further research is needed to conclusively determine the efficacy of steam balancing measures?

\subsection{Technical Approach}

A package of common steam balancing measures (replacing radiator vents, increasing or upgrading main line air venting, and indoor averaging boiler controls) was assembled and data were collected on 10 buildings before and after these retrofits were installed. This project built on the relationships between building owners and contractors and the CNT Energy Savers Program. ${ }^{1}$

All the building owners involved in this project had previously worked with the CNT Energy Savers Program, so all the potential test buildings had already received energy assessments. An initial pool of candidate buildings was identified according to the following criteria:

- Single-pipe steam heating system

- $15-30$ units

- Uneven heating throughout the building (based on qualitative observations from the auditor, building manager, and/or tenants)

- Boiler in proper working order.

Boiler replacement was not tested in this study, so the boiler had to be in good working condition for a building to participate. This was assessed both from information collected during the previous energy audit and from the steam heating contractor about the boiler condition and its regular maintenance.

The previous assessment data and reports were reviewed and candidate buildings were re-visited by a CNT energy analyst. The buildings were then examined by a Chicagoland steam heating contractor who diagnosed the building's problems and submitted a scope of work for each building. Final test buildings were chosen based on, among other criteria, the steam measures recommended, potential for energy savings, and building type (see Figure 1).

\footnotetext{
${ }^{1}$ Energy Savers is a program run by CNT Energy that works with multifamily building owners in Chicagoland to identify cost-effective energy efficiency measures and connect them with resources to implement these upgrades (Evens, Ludwig, and Kotewa 2008). Since 2007, the Energy Savers program has retrofitted more than 7,500 units for efficiency.
} 

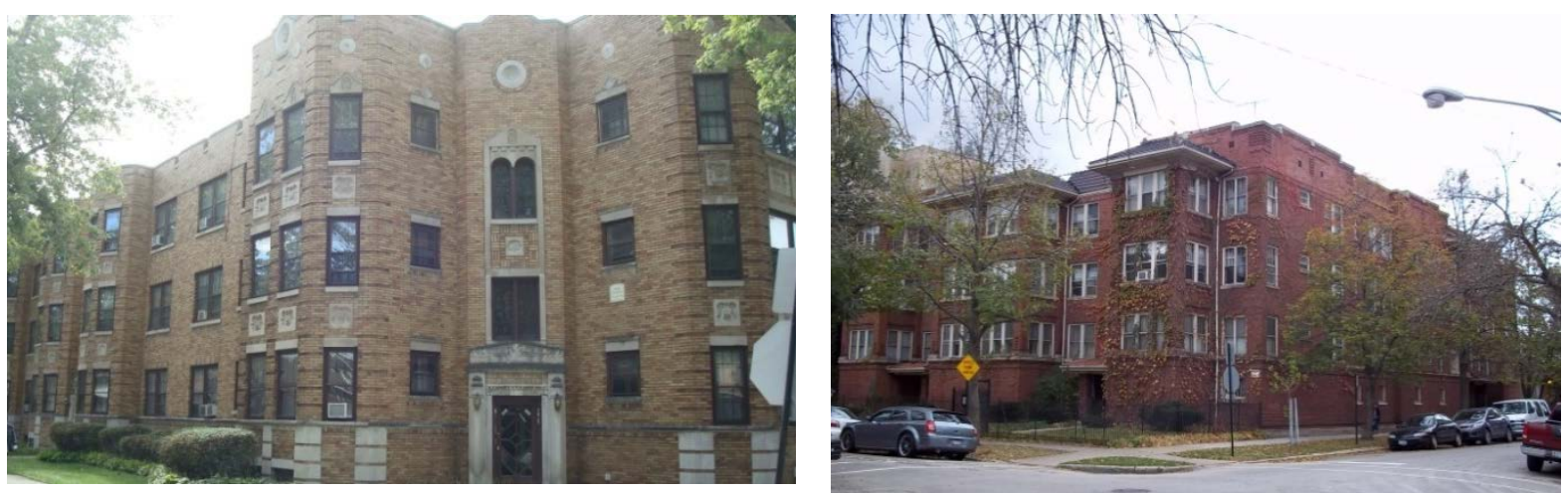

Figure 1. Two of 10 test buildings. The buildings chosen were brick three-story walk-ups, a common structure for multifamily housing in Chicago. See Appendix A for specifications on all of the test buildings.

(used with permission from CNT Energy, 2011)

Access to units and the boiler room is an important factor for assessing and fine-tuning a building's steam heating system, so the relationships and communication between the building owner and his or her tenants were also considered in choosing buildings. Regular communication with tenants (both to ensure minimal tampering with the data collection and for ready access to the apartments) was necessary for project success. Tenants were given notice by their building managers before each visit and letters explaining the project (a sample of which can be seen in Appendix B) were distributed during the data collection periods.

\subsection{Assessment of One-Pipe Steam Heating Systems: What To Look For}

After the test buildings were selected, their heating systems were subjected to rigorous testing and analysis to determine their current effectiveness. Steam performance had to be thoroughly assessed to properly evaluate the effectiveness of a package of steam balancing measures. To provide this analysis, comprehensive measurements and monitoring of system components were essential before and after the packages of steam balancing measures were installed. After an initial overview of one-pipe steam systems to clarify the details and design of the experiment, this section was divided into subsections to (1) indicate which system components particular data relate to; and (2) outline the guidelines for studying the behavior of a particular component. All these components should be carefully examined when a building is being balanced. The following subsections detail which parts were carefully examined in this study and provide general guidance for a steam system assessment.

\subsubsection{Overview of One-Pipe Steam Systems}

Chicago's multifamily housing stock is predominantly heated by central steam or hydronic systems. Single-pipe steam heating was the best option for buildings constructed between 1900 and 1930. Though these systems have been converted from coal to gas and many have undergone boiler replacement or other small upgrades, the distribution systems remain largely the same as when they were first installed. Single-pipe steam systems were designed for longevity but not for energy efficiency (Peterson 1985). Typical single-pipe steam systems are controlled on a timer or by a single thermostat. When the thermostat or timer calls for heat, the boiler comes on, heats the water, and generates steam. The steam moves through the piping that is initially full of air, 
heating the metal and pushing the air out through vents on the main distribution lines and radiators. As steam reaches each vent, the vents close so no steam escapes. Within each radiator, the steam condenses and releases latent heat, allowing more steam to enter. The water that has condensed inside the radiators runs back through the same distribution lines to the boiler. When the building has been heated according to the thermostat or timer's specifications, the boiler shuts off. As the radiators cool, the air vents open and allow air to re-enter the system. A schematic of this entire system is shown in Figure 2.

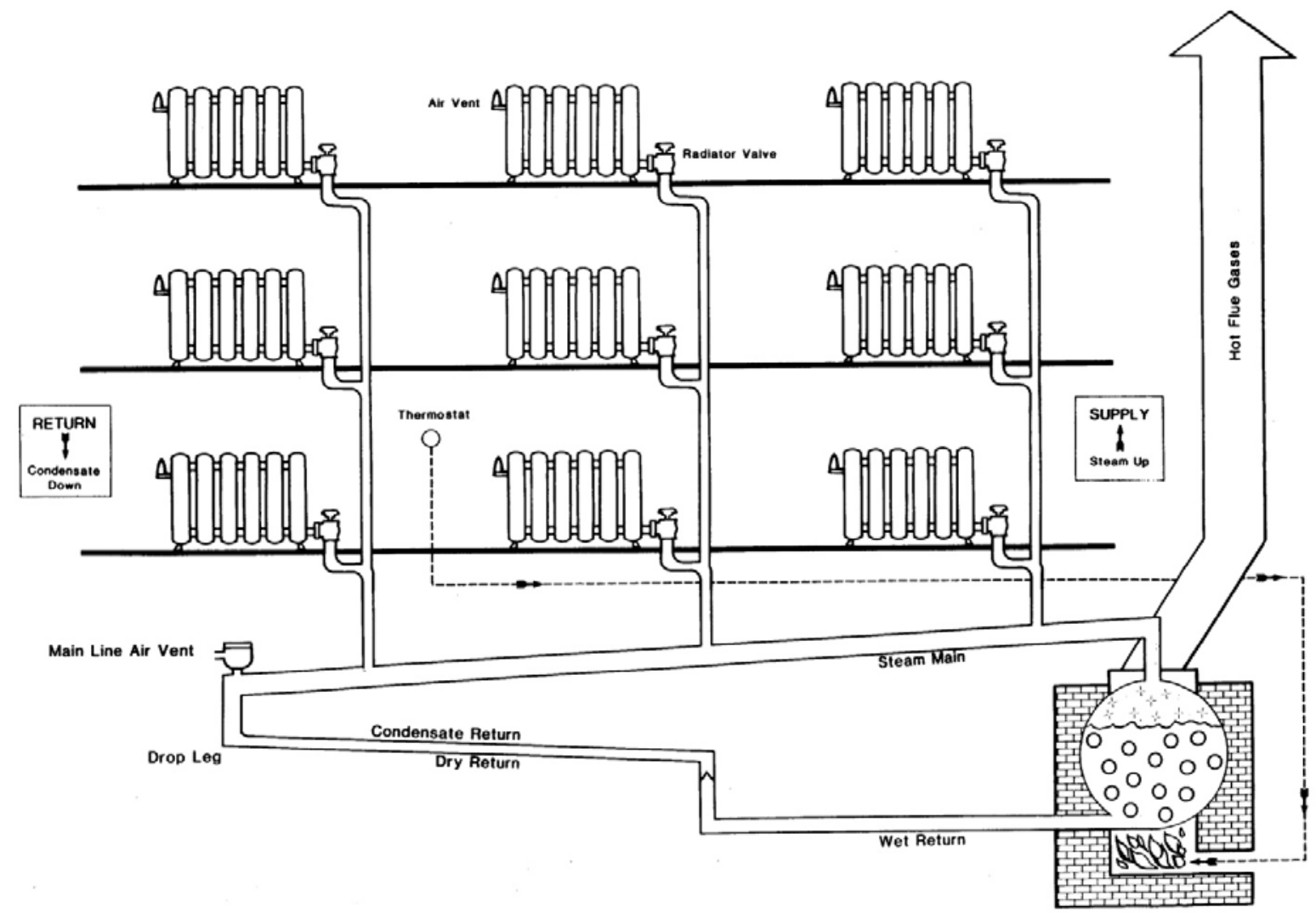

Figure 2. Schematic of single-pipe steam system

(adapted from Peterson 1985)

Large differences in steam arrival times, excessively short boiler cycles, lack of zone control or temperature averaging, and variable steam main lengths can all contribute to uneven heating in a building (Peterson 1985). When considering how to solve these issues, the following factors should be assessed.

\subsubsection{Main Line Air Vents}

\subsubsection{Guidelines}

The purpose of main line air vents is to rapidly vent the large amounts of air in the steam lines. These vents lower the back pressure during the fill part of a boiler cycle and aid the flow of steam down the main distribution pipes. Without main line air vents, all the air in the lines must be purged at the radiators, in which case steam would fill the radiators closest to the boilers much faster than those furthest away. This can cause uneven heating, particularly if the boiler shuts off before the whole system is full (see Figure 3). As such, there should be at least one main line air 
vent per steam loop. Proper air venting can be used to control the relative speed of steam delivery to radiators in various parts of a building. Main line air vents should be installed on the main distribution lines after the last riser and before the dry return drops into the wet return. The valve is open until the steam reaches it, at which point it shuts and prevents steam from escaping through it (Peterson 1985).
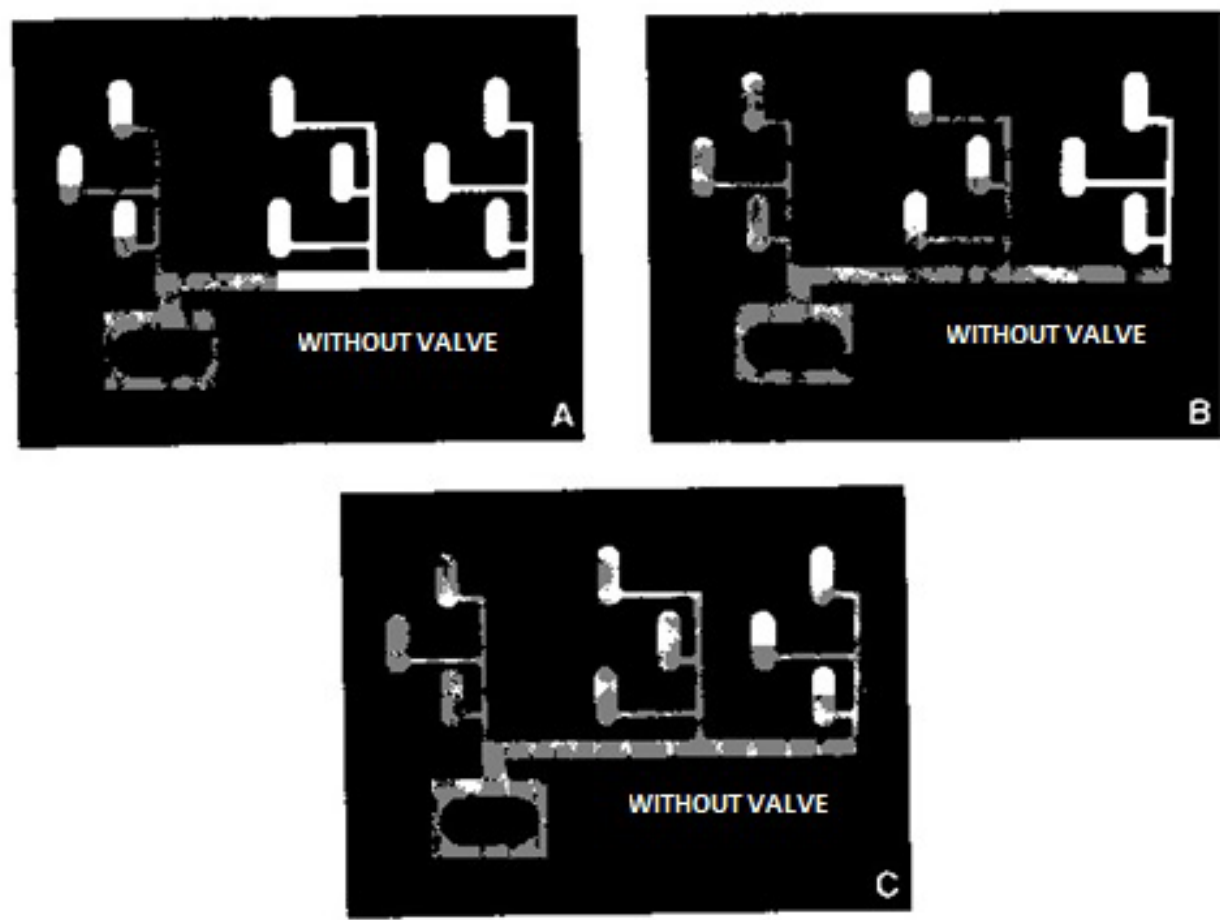

Figure 3. At the beginning of a boiler firing cycle, the piping system and radiators are filled with air and quite cool, meaning that the steam must heat a large mass of piping and push air out of the air vents. The furthest radiators will receive heat more slowly than the closest. As shown in (C), in the absence of main line vents, steam may never even reach the furthest radiators if the boiler shuts off before it can reach them.

\subsubsection{Method}

(adapted from Peterson 1985)

Data for the main line piping consisted of:

- A census of all the main line loops in the building

- The approximate length of each main line loop

- Varying thickness of pipe for each main line loop

- Pipe insulation for each main line loop

- Positions of vertical tiers on each main line loop

- Positions of vents on each main line loop

- $\quad$ Sizing and condition of main line vents. 
Each basement was inspected and the number and condition of the main line air vents was determined for each building. Vents are often hidden in unused basements or storage facilities and a thorough inspection was conducted to assess the current efficacy of the venting. This information was then either confirmed by or relayed to the heating contractor for determination of which vents needed to be replaced or whether vents needed to be added to the distribution lines.

\subsubsection{Near Boiler Piping}

\subsubsection{Guidelines}

The quality and effectiveness of steam heating can be affected as much by the near boiler piping (NBP) as by the boiler or main line pipes. As steam boilers are replaced, their accompanying piping is often incorrectly configured to be either too large or too small. Figure 4 shows an example of an insufficiently sized replacement header. The largest diameter piping should always be closest to the boiler to accommodate the massive amounts of steam it generates and to allow the steam to move efficiently through the rest of the distribution system.

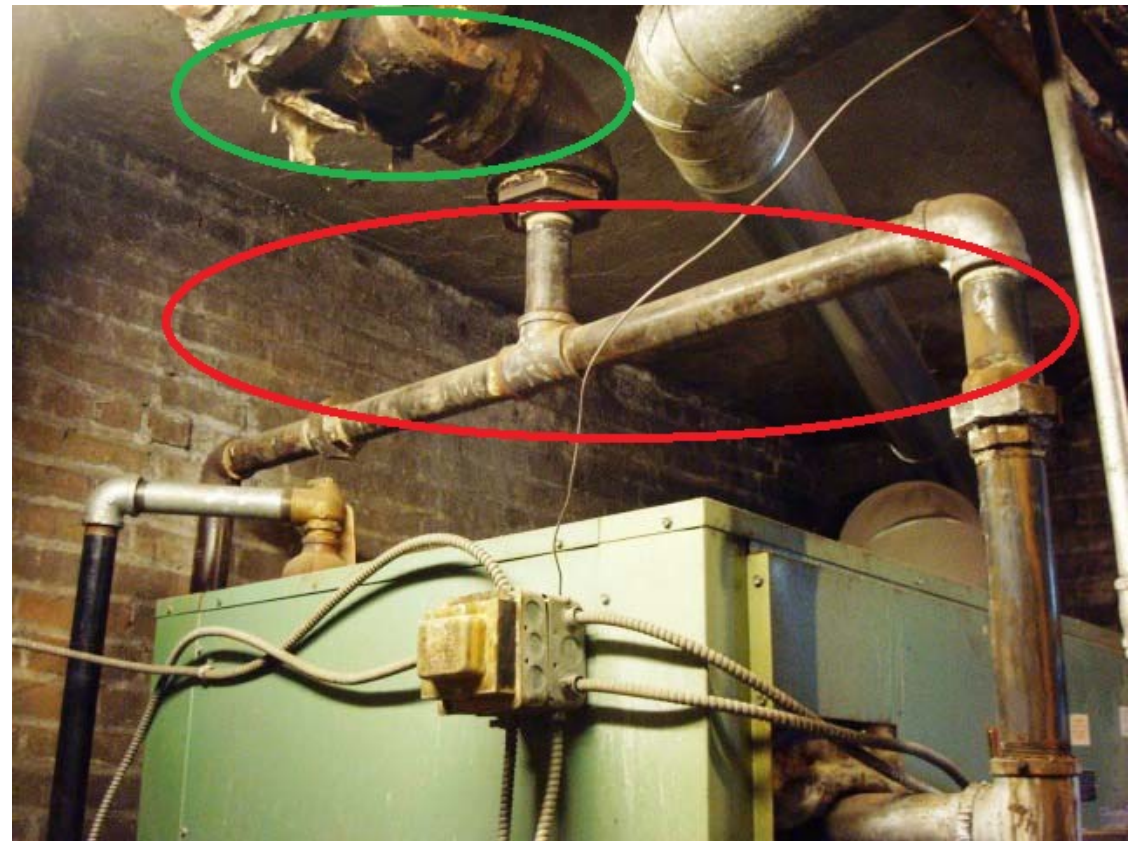

Figure 4. The original header piping on this boiler was 4-6-in. diameter whereas the new piping is only 2 in.

(used with permission from CNT Energy, 2011)

As shown in Figure 5, the risers leading from the boiler takeoff to the header piping should be at least $24 \mathrm{in.}$ The supply line leading from the header should not be directly aligned vertically with any of the risers or with the equalizer. This configuration ensures that wet steam, which decreases the amount of latent heat available from the steam and therefore decreases the efficiency of the system, will not be able to get into the header piping or supply lines. The steam must be dry to reach the furthest radiators. The boiler manufacturer's specifications provide instructions about how to correctly pipe a boiler (see Figure 5 for an example). The NBP should also include a Hartford Loop, which acts as a backup safety measure to the low-water cutoff. If a return line breaks, water can only back out of the boiler to the point where the wet return line 
connects into the equalizer. The loop acts as a siphon that runs out of water, stopping the boiler from emptying completely. Water cannot vanish instantly from the boiler, so the loop allows for additional time to notice the problem and have it fixed (Holohan 2010a).

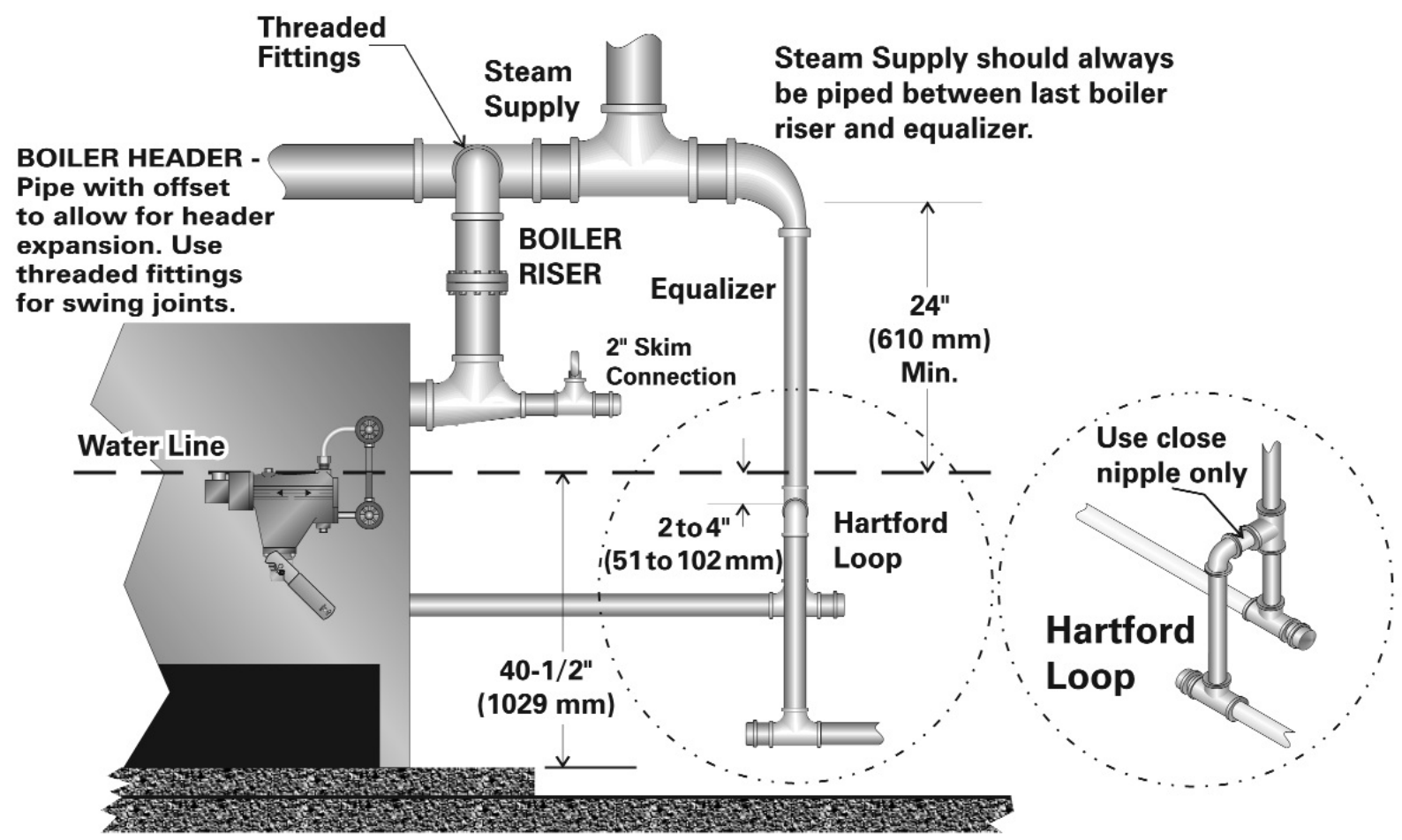

Figure 5. Specifications for how to pipe a Series 211A natural gas steam boiler by Peerless

As shown in the diagram, the boiler risers should always be at least $24 \mathrm{in}$. long and the steam supply should always be piped between the last boiler riser and the equalizer.

(Peerless Boilers)

\subsubsection{Method}

Data acquisition for the NBP consisted of:

- Height of the header piping

- Width of risers and header

- Descriptive geometry of the NBP.

The NBP was examined at each test building and, if necessary, corrected before the data logging period or before any other steam balancing measures were installed. One of the 10 buildings had incorrectly installed NBP that had to be corrected.

\subsubsection{Boiler Controls}

\subsubsection{Guidelines}

Steam heating systems are often controlled by a single thermostat, or an aquastat and time clock. All 10 buildings were controlled by one of these two setups. Although they can tell a boiler when 
to turn on and off, these controls do not consider temperature variations within a building. They are often switched on and off manually by building maintenance staff, depending on tenant feedback. The steam systems accompanying these controls are usually unbalanced, so some apartments are $10^{\circ}-15^{\circ}$ too warm while others receive little to no heat.

\subsubsection{Method}

Data acquisition for the boiler and boiler controls consisted of:

- $\quad$ Rated boiler capacity (Btu/h)

- Boiler size (number of sections)

- Burner condition

- Boiler firing pattern

- Combustion analysis (steady-state annual fuel utilization efficiency (AFUE), carbon monoxide, carbon dioxide, oxygen)

- Description of control type

- Daytime and nighttime set points

- Observation of how controls are being operated by maintenance staff.

A boiler runtime sensor and data logger were wired to the boiler in each test building to assess and monitor the patterns of the current boiler controls. These sensed when an alternating current was running between the current control system and the boiler and logged the duration until it was shut off to determine the boiler cycle patterns. Looking at the intervals when the boiler is on can provide valuable information about the average length of a boiler cycle and how much heating fuel the boiler is using. In addition to information about the controls, basic information about the boiler (input rating in Btu/h, AFUE, etc.) is important for analysis and was recorded during the early site visits.

\subsubsection{Radiator Vents}

\subsubsection{Guidelines}

Just as the distribution of steam heating is affected by the condition of the main line air vents, it is also affected by the condition of the radiator air vents. If an apartment unit is too cold, the heat input must be increased or the heat loss decreased (Peterson 1985). Often this can be achieved by replacing radiator air vents that are blocked or not functioning properly.

If no steam ever reaches one or more radiators, the radiator valve should be checked to see if it is open and operating properly. If the vent is loudly whistling when the radiator fills with steam, its orifice may be too small and in this case, the vent should be replaced. A whistling vent could also be indicative of debris clogging the opening or the boiler operating pressure being higher than necessary. Alternatively, if an apartment is too hot, the steam reaching the radiators can be slowed by a smaller vent. Though studies have shown that there is a point at which an increased orifice size has little influence on fill time (Peterson and Otterson 1985), proper air venting can be an effective way to largely control the relative speed of steam delivery to various radiators. 
Figure 6 shows an example of a radiator vent that comes in different models of varying orifice size.

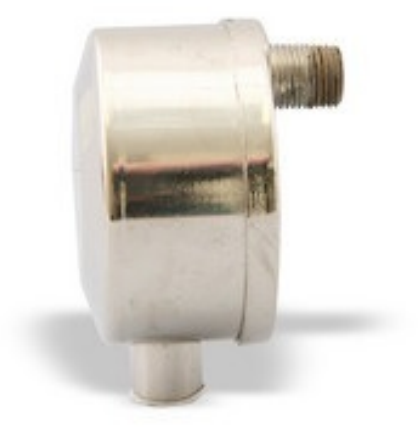

Figure 6. Gorton No. 4 angle radiator vent. Gorton models are made in No. 4, 5, 6, C, and D, ranging from 4 with the smallest orifice (for warm apartments) to $D$ with the largest (for cool apartments)

(Gorton Heating 2006)

The size of the radiator is also important when considering the appropriate vent size. Big radiators contain more air than small ones, so big radiators need larger air vents to fill with steam more quickly. Two vents can be used on oversized radiators; a second vent can be positioned a few inches lower than the first and the two vents will work together to vent the air. Once the steam reaches the first vent and closes, the second air vent will continue to vent air. The oversized radiator will thus heat more completely (Holohan 2010b).

\subsubsection{Method}

Data collected about the radiator vents consisted of:

- A census of a sample of radiators in the building

- The size and condition of radiator vents.

The radiator air vent should be removed and tested; if it is not passing air, it should be cleaned or replaced. Figure 7 shows the common problem of a radiator vent that has been painted over and no longer works. 


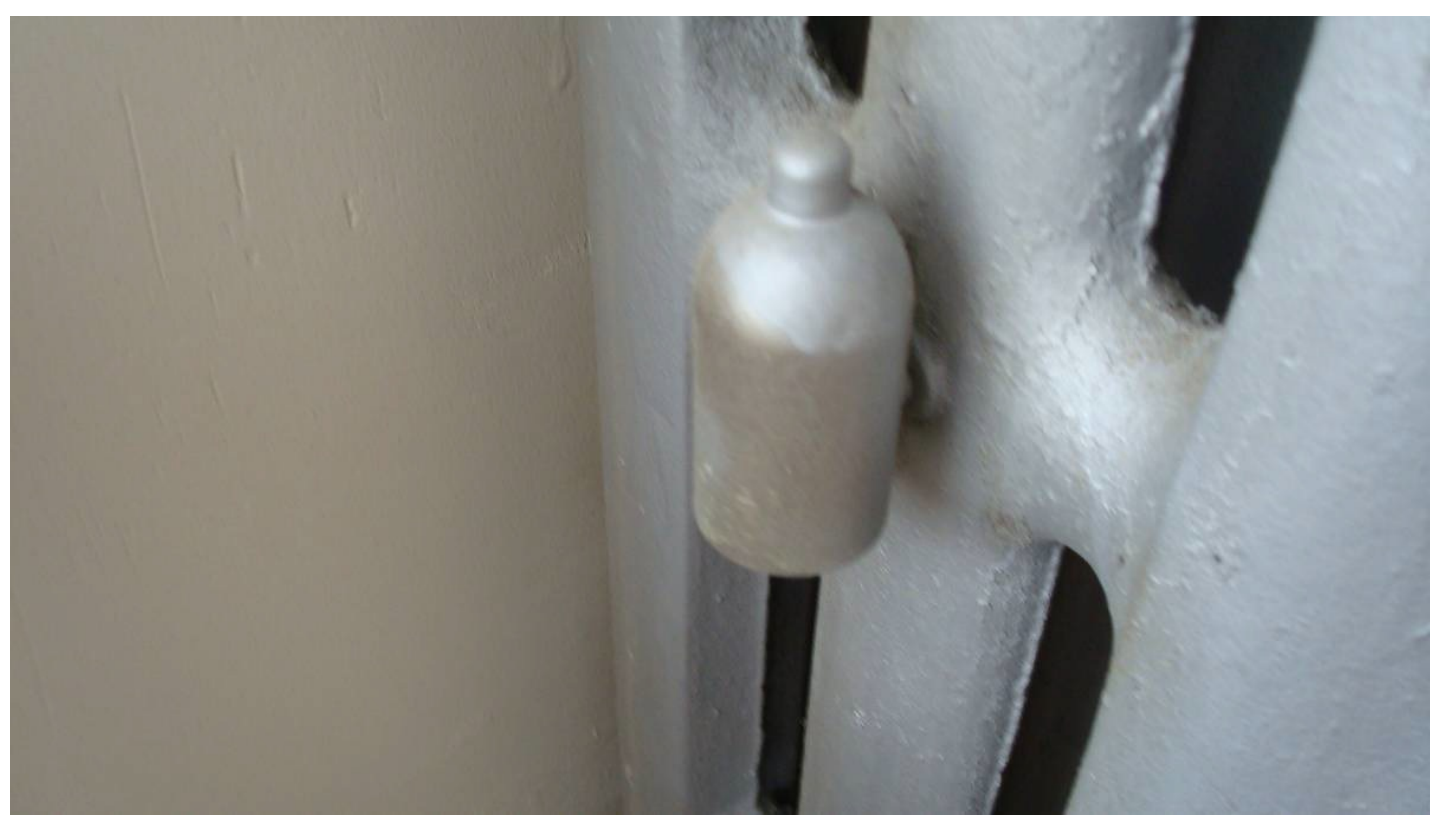

Figure 7. Painting over radiator vents is a common oversight that can have a serious effect on the heating in an apartment. Blocked radiator vents must be replaced.

(used with permission from CNT Energy, 2011)

For this study, the condition of the radiator vents in a sample number of units was examined and an assessment was made about whether to replace some or all of the vents. Adjustable air vents can be considerably more expensive and subject to tampering by tenants (negating their usefulness of being able to adjust to the location and size of the radiator); they were therefore not used in this study. Removing, rearranging, or replacing radiators can be difficult and expensive and were also not considered in this study.

\subsubsection{Temperature}

\subsubsection{Guidelines}

Many factors influence the temperature of a given unit at a given time, making this piece of data extremely dynamic and challenging to capture. However, temperature changes over the course of the steam heating cycles, the day, and the heating season, are important to studying the distribution of heat in a steam-heated, multifamily building. Identifying the patterns of temperature change over these time periods can help researchers infer exactly how the heating distribution is failing. Units closer to the boiler were predicted to be warmer and those further were predicted to be cooler; however, the temperature data collected enabled a confirmation of these predictions.

\subsubsection{Method}

Temperatures in each building were measured with high resolution across locationally and thermally diverse units. Matching the temperature in a broad cross-section of units with the rest of the data acquired for each building - outside temperature, boiler firing pattern, ventingenabled a thorough analysis of steam heating systems and the effects of steam balancing measures. The data were recorded for one month before and after the steam balancing measures were installed, ensuring a broad picture of system behavior and enabling control of abnormal 
climactic variation. Both the pre-measure and post-measure logging periods were during the 2011-2012 heating season.

Table 1. Logger Equipment

\begin{tabular}{c|c|c}
\hline Measurement & Model & Description \\
\hline Outdoor Air Temperature & HOBO U23 Pro v2 & $\begin{array}{c}\text { Outdoor temperature/relative } \\
\text { humidity data logger } \\
\text { Indoor temperature/relative } \\
\text { humidity data logger }\end{array}$ \\
$\begin{array}{c}\text { Indoor Air Temperature } \\
\text { BC Current/Boiler State } \\
\text { (On/Off) }\end{array}$ & HOBO U10-003 & State logger \\
\hline
\end{tabular}

Temperature data loggers were placed in six units in each building and recorded the temperature every five minutes for four weeks. The loggers were placed in units directly above the boiler (predicted to be the most overheated) and in units that were furthest from the boiler (predicted to be receiving the least heat) on at least two floors to capture the diverse temperatures at any given time. They were placed uniformly at around five feet from the ground, and were not placed on external walls, above radiators, or in kitchens or bathrooms. The buildings used in this study were typically three-story brick walk-ups. (For a detailed description of the buildings used, refer to Appendix A.)

Temperature loggers and boiler runtime loggers were also placed in the boiler rooms and an external logger measured outside temperatures. Table 1 lists the logger equipment that was used for this study. Figure 8 depicts a test building and a typical setup for the data logger placement. Schematics of each building and detailed locations of the loggers were carefully recorded. 


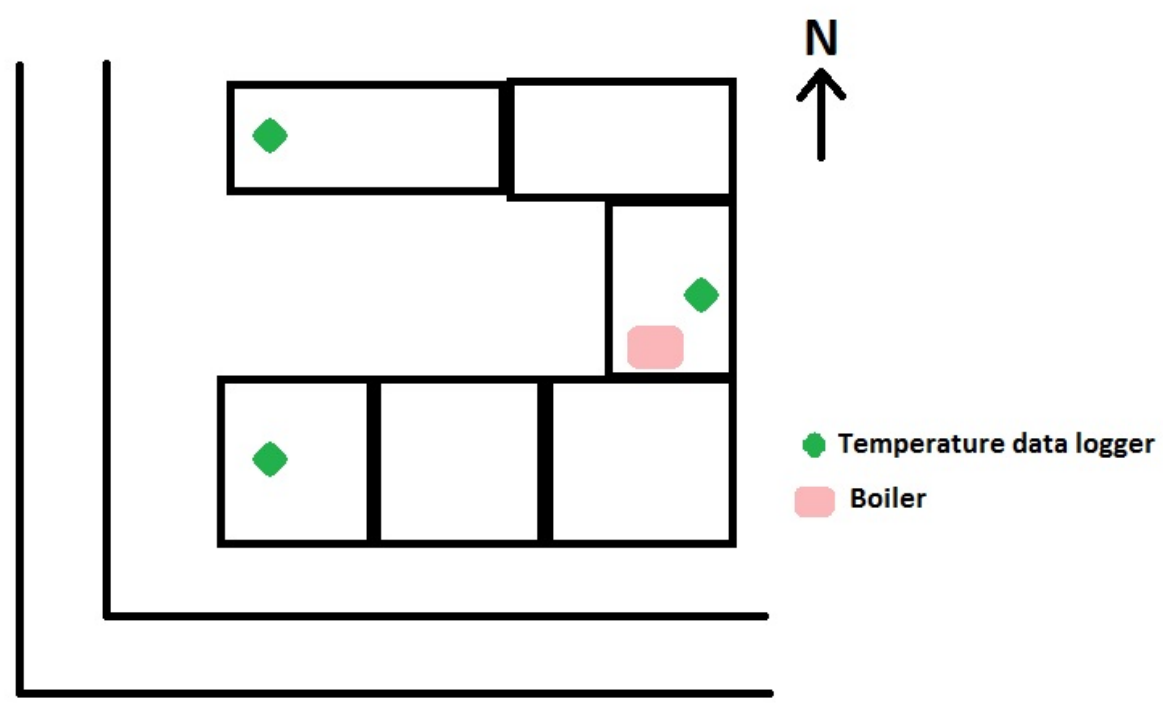

Figure 8. Schematic plan of a building in the study

Temperature loggers were placed at three locations on each of the first and third floors (a total of 6 units): two loggers in the units directly above the boiler, two in the north wing, and two in the

\subsubsection{Tenant Comfort} south wing.

\subsubsection{Guidelines}

Interviewing the tenants and building manager enables a comparison of temperature data to the residents' perceptions of the heat. It may also be useful in explaining abnormalities in the temperature data. If a unit far from the boiler, and therefore predicted to be cold, shows higher than average or expected temperature readings, the tenants may be using space heaters or the oven to additionally heat their unit. If a unit close to the boiler, and therefore predicted to be warm, shows lower than average or expected temperature readings, the tenants may be opening their windows. Also, surveying the tenants is useful in determining which parts of the building are too cold and which are too hot, especially in the absence of sensors.

\subsubsection{Method}

A tenant survey is an inexpensive method of understanding tenants' perceptions of the heating in their apartments and information about how the system operates (Peterson 1986). A tenant comfort survey was conducted in this study when the pre-measure temperature data were collected (before any steam balancing measures were done) and when the post-measure temperature data were collected (after the steam balancing measures were completed by the contractor). (A copy of this survey is shown in Appendix C.) The survey was administered by the CNT energy analyst collecting the data and the responses were recorded in the field. This was predicted to yield a more successful response rate than written surveys requiring additional action from the tenants. 


\subsection{Measurement Methods}

Although most of the data (other than the temperature data and boiler runtime data) were collected by observation during the site visits, some additional equipment was necessary for the study. Table 2 outlines the equipment needed for data acquisition.

Table 2. Measurements and Equipment

\begin{tabular}{|c|c|}
\hline Measurement & Equipment Needed \\
\hline Census of Radiators & Observation \\
\hline Radiator Vent Size & Observation \\
\hline Radiator Vent Condition & Observation \\
\hline Census of Main Lines & Observation \\
\hline Main Line Lengths & Laser distance meter \\
\hline Thickness of Main Lines & Calipers \\
\hline Vertical Tier Position & Laser distance meter \\
\hline Position of Vents & Laser distance meter \\
\hline Main Vent Size & Observation \\
\hline Main Vent Condition & Observation \\
\hline Main Line Steam Time & Infrared camera \\
\hline Rated Boiler Capacity (Btu/h) & Observation \\
\hline Boiler Size (sections) & Observation \\
\hline Burner Condition & Observation \\
\hline Boiler Efficiency (AFUE) & Combustion analyzer \\
\hline Header Piping Height & Laser Distance Meter \\
\hline Riser and Header Width & Calipers \\
\hline NBP Geometry & Camera \\
\hline Return Line Condition & Observation \\
\hline Description of Boiler Controls & Observation \\
\hline Number of Functioning Sensors & Observation \\
\hline Daytime/Nighttime Set Points & Observation \\
\hline Current Boiler Operation & Observation \\
\hline
\end{tabular}




\section{Measure Implementation}

\subsection{Determining a Scope of Work}

CNT Energy worked with a Chicagoland steam heating expert contractor to develop a final scope of work for each test building. These scopes were highly detailed. It was decided that one contractor would do all the work, as this would minimize variability in installation methods, techniques, materials, and cost, and thus enable a consistent analysis of the effect of the main measures for a steam balancing package. The contractor proposals included itemized costs and descriptions of each steam balancing measure, informing the analysis on cost effectiveness.

\subsection{Measure Costs}

When examining the scopes of work for balancing the steam systems of the test buildings, the measures most frequently recommended by the resident steam heating expert were:

- Adding or replacing the main line air vents

- Replacing the radiator vents

- Upgrading or adjusting the boiler control system.

Table 3 summarizes the average costs for each measure.

For a detailed breakdown of all of the measures completed on each building (between December 2011 and January 2012) as well as their cost breakdowns, see Appendix D.

Table 3. Average Costs for Common Steam Balancing Measures

\begin{tabular}{c|c}
\hline Measure & Average Cost \\
\hline Adding or Replacing Main Line Air Vents & $\$ 1,800$ \\
Replacing Radiator Vents & $\$ 3,680$ \\
\hline Upgrading Boiler Control System & $\$ 5,060$ \\
\hline
\end{tabular}




\section{Analysis}

Most of the savings of steam system balancing were predicted to come from temperature control and improved heat distribution. Many strategies can be used to achieve more uniform distribution; thus, one of the larger goals of this study was to evaluate the main strategies used to balance these complex systems. To accomplish this goal, the project made detailed observations about how the steam systems behaved before the balancing. These data informed decisions about the final scope of work, and were monitored after the balancing to measure the effectiveness of the installed measures.

\subsection{Temperature Control and Steam System Behavior}

An important part of the analysis of the steam system behavior was centered on the highresolution data about indoor air temperature in the units. More uniform air temperatures will theoretically lower energy bills and improve tenant comfort. As described in the Technical Approach, six units in each building were fitted with temperature data loggers that recorded readings every five minutes for one month before the steam balancing, and for one month afterward.

The temperature data were analyzed by looking at the average temperature of each logger at each hour of the day over the pre- and post-measure logging periods. Each building reacted differently to the balancing work; however, Figure 9, through Figure 12 show samples of these data in graphical form. These represent the fluctuations during a day and the temperature differentials between units.

Building 5, for example, experienced a significant change in temperature shift patterns that was uniform across all units. Instead of allowing the boiler to heat the units at night when it is typically not needed, the indoor averaging boiler controls appeared to be regulating the unit temperatures to be warmer in the early morning (when tenants may be waking up) and in the early evening (when tenants may be getting home from work). Figure 9 shows that pre-retrofit, Building 5 was being heated to its highest temperatures between midnight and 2:00 a.m. Figure 10 shows that post-retrofit, it was being heated from 7:00 a.m. throughout the day, when tenants are more likely awake and in need of heat. The averaging systems that were installed in all the test buildings appeared to be more tightly regulating the temperatures in the units than the thermostat or timer mechanisms originally in use. 


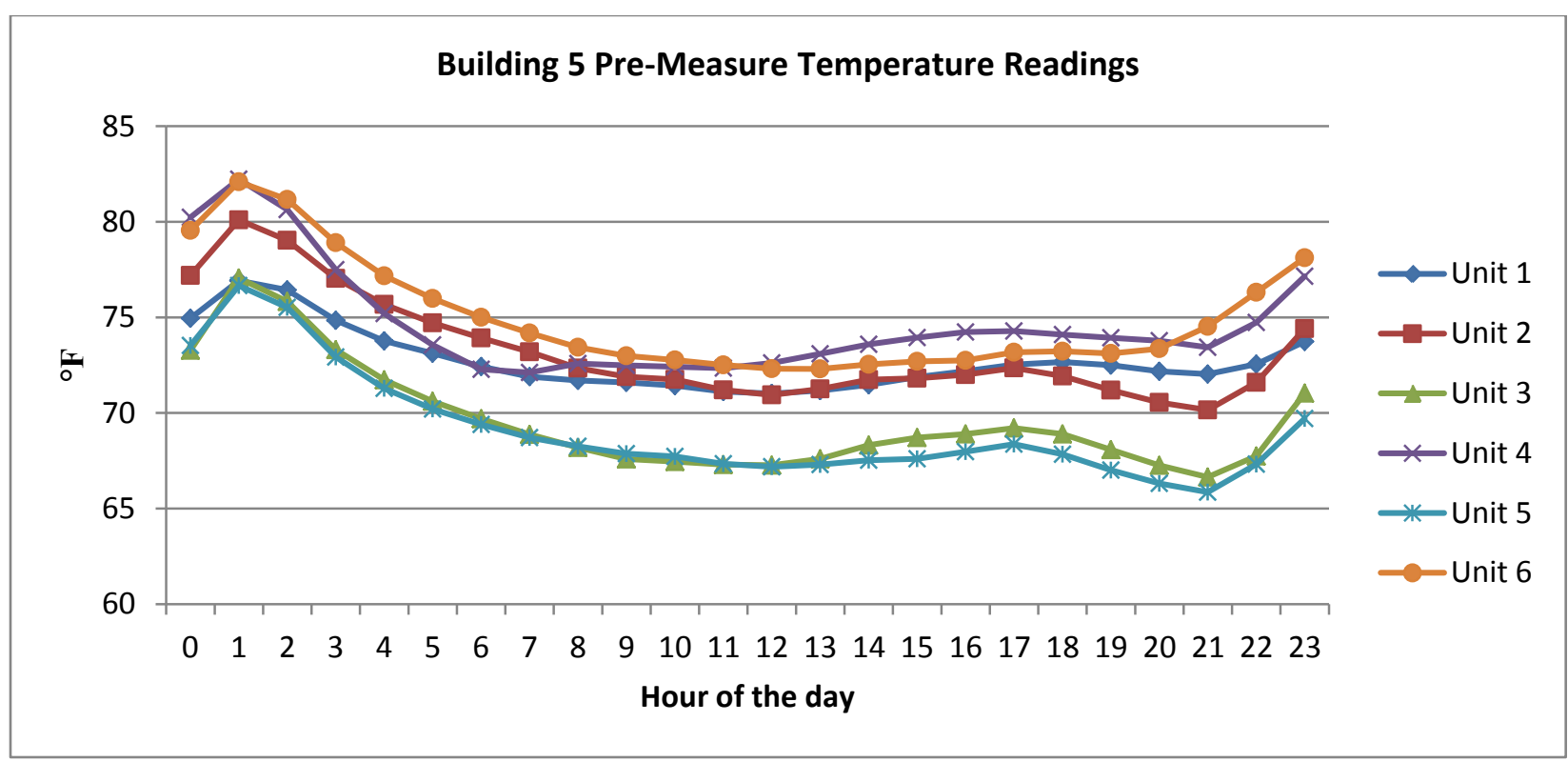

Figure 9. Building 5 average pre-measure logging period temperature readings by hour of the day

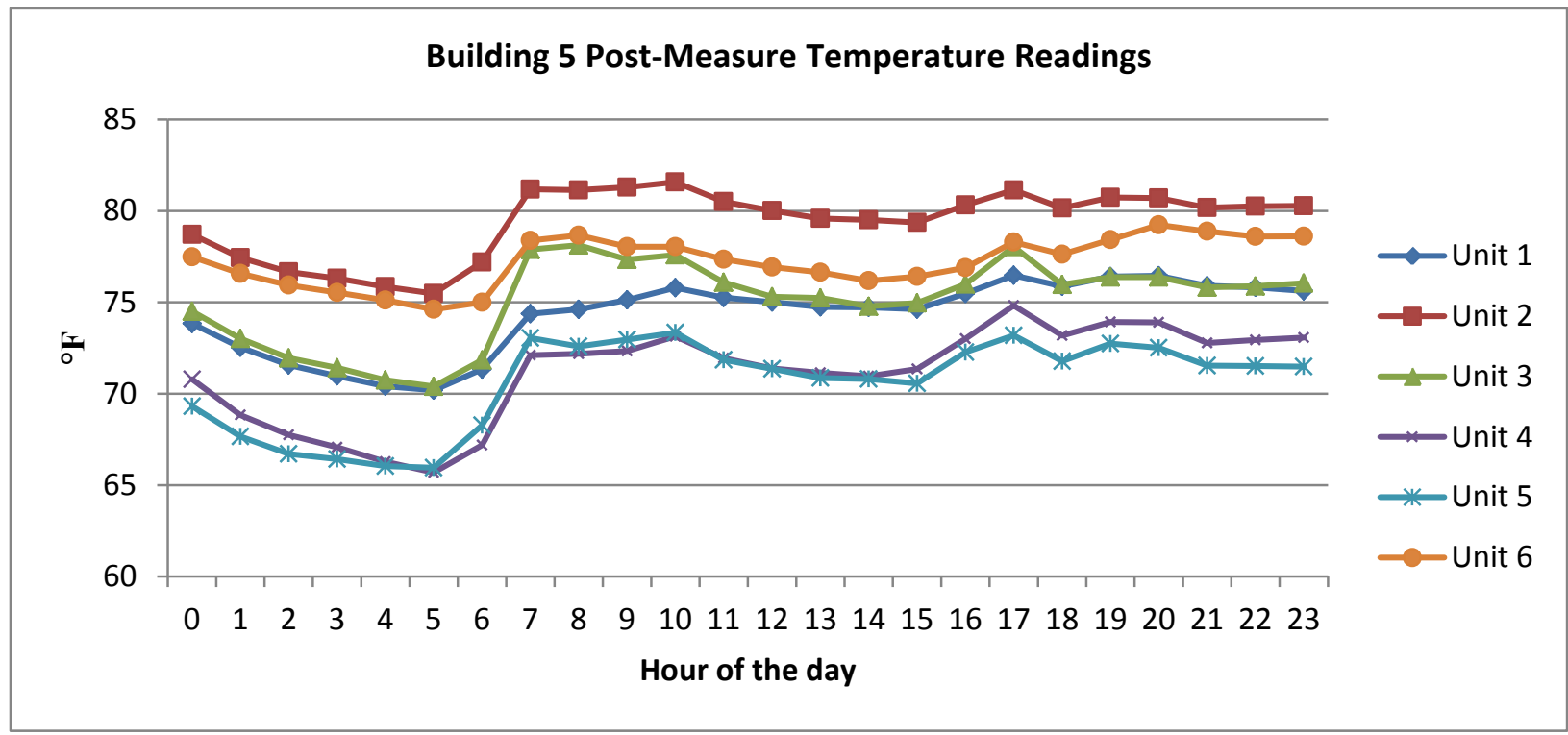

Figure 10. Building 5 average post-measure logging period temperature readings by hour of the day

In Building 4 (see Figure 11 and Figure 12 for temperature data), the two coldest units (Units 2 and 4) pre-retrofit showed an increase in temperature by about $2^{\circ}$ overall post-retrofit. The temperature differential between the hottest and coldest units was therefore decreased, suggesting an evener distribution of heat throughout the building. The manager also reported that heat seemed to be reaching the extreme ends of the building more quickly and evenly. Building 2 similarly showed a tighter band of temperature differences post-retrofit, suggesting that the heat was being more evenly distributed. 


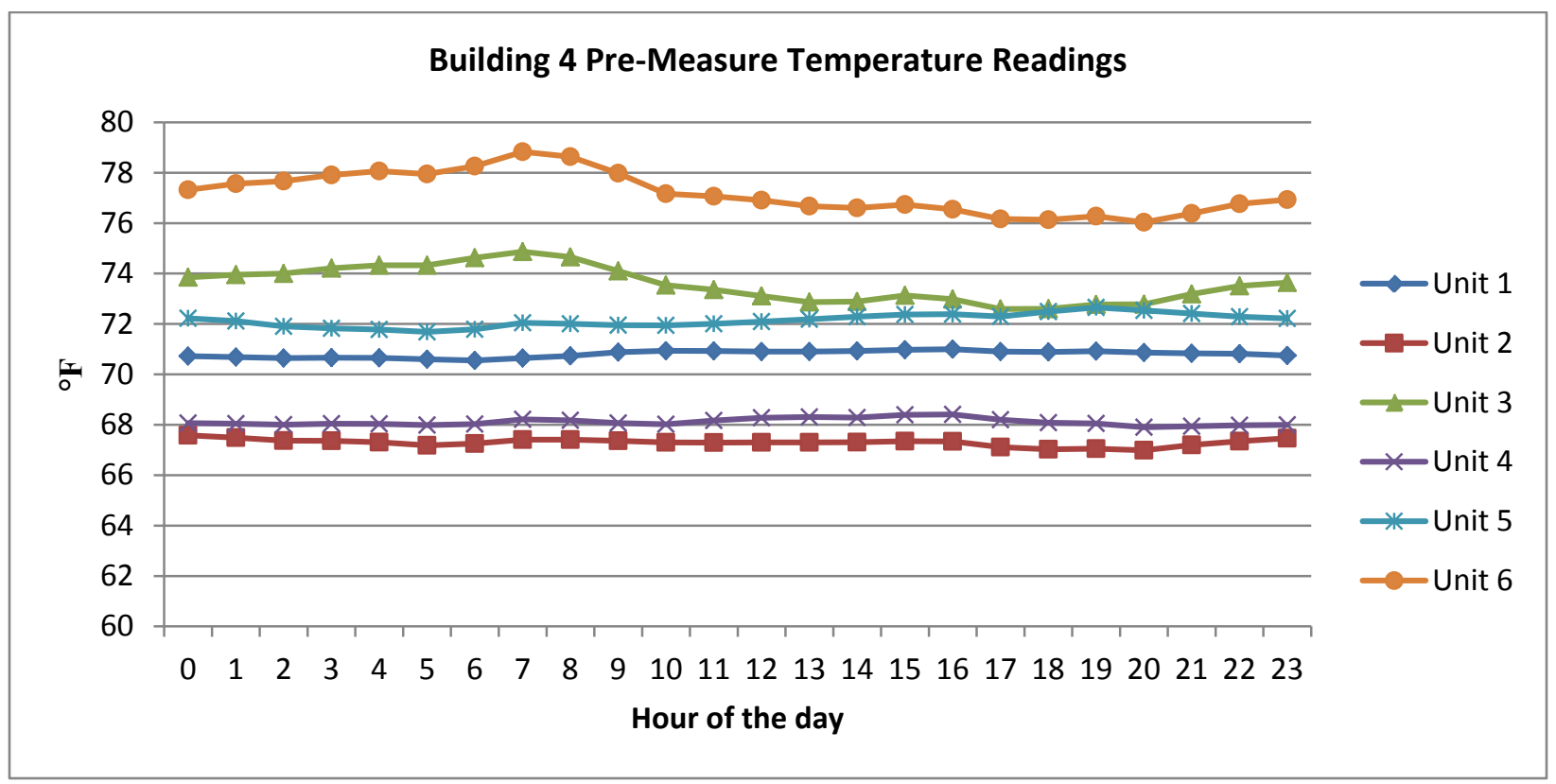

Figure 11. Building 4 average pre-measure logging period temperature readings by hour of the day

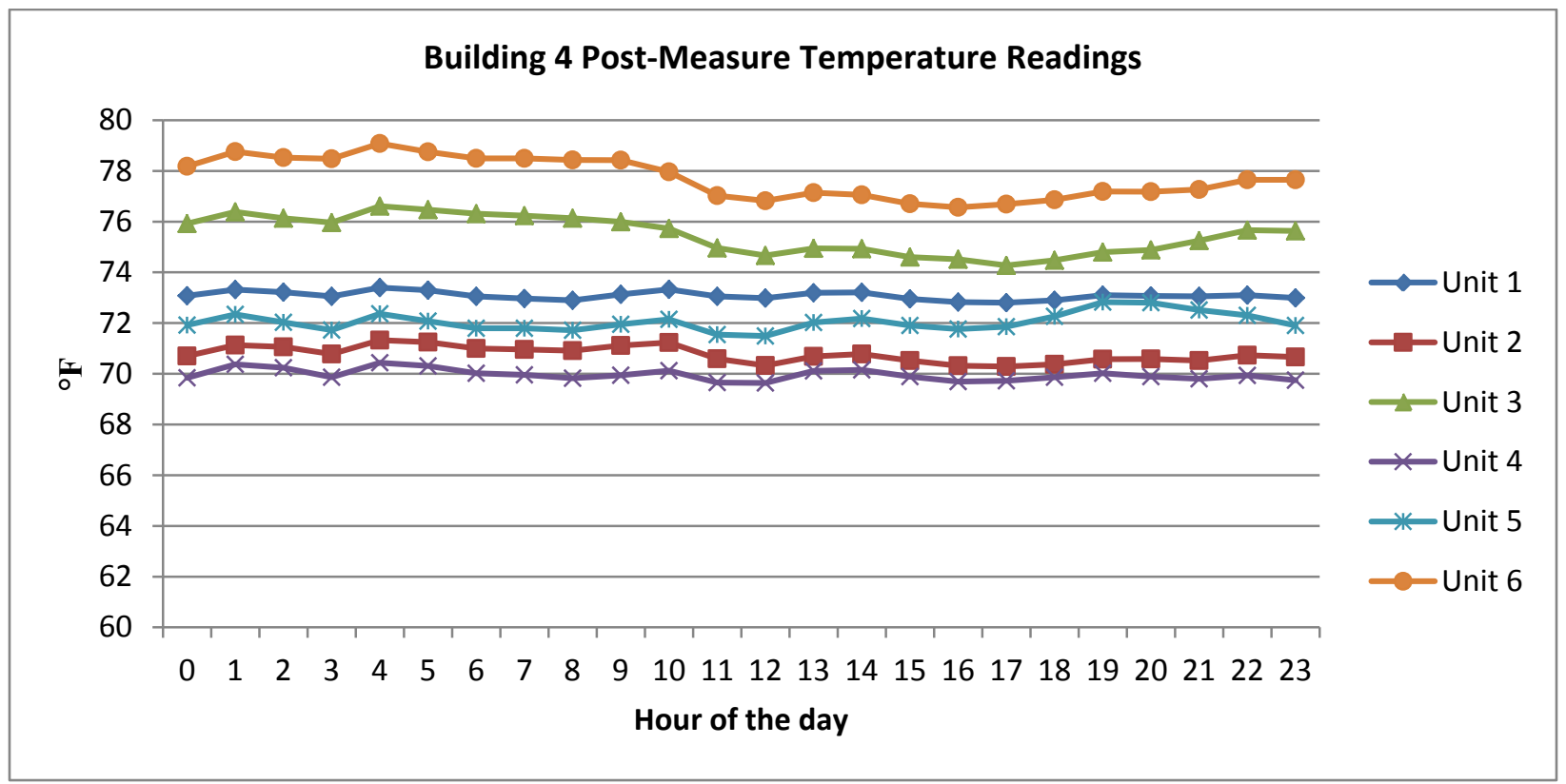

Figure 12. Building 4 average post-measure logging period temperature readings by hour of the day

Building 10 showed an increase in overall temperature across all units. The post-retrofit oversight visit revealed that the owner had increased the set point temperature on the new boiler controls. This explains the uniform temperature increase, because the distribution of temperatures remained the same. The operation and settings of the boiler controls were important 
factors in this project. Although the building owner or manager should decide how to set the controls (based on feedback from his or her tenants), this will be an important factor in whether the building can save on energy costs after balancing work is done. Proper building manager education on operating more complicated boiler controls is a very important step to steam balancing. If Building 10 is using less natural gas over the course of its continued monitoring, this suggests that the increased main line venting and upgraded radiator vents are allowing the steam to reach the apartments more quickly and efficiently. This enables the building owner to save natural gas and money, even though the temperature set points on the controls are higher.

The information collected from the tenant surveys revealed that many tenants in the coldest units were using space heaters or their ovens for additional heat on the coldest days of the logging periods, which could raise the average temperatures of units. Information from the tenant surveys was used as much as possible to determine the validity of the temperature readings.

\subsection{Boiler Cycles}

Calculated from the data recorded by the boiler runtime loggers, the numbers of times that the boilers cycle on each year are shown in Table 4. Also shown for each building are the average lengths of the boiler cycles and the weather-normalized percent of time each boiler was on per day.

Four of nine buildings showed less frequent boiler cycles and seven showed shorter boiler cycles post-retrofit. 
Table 4. Cycle Counts per Year, Average Lengths of Boiler Cycles and Percent of Day Boiler On

\begin{tabular}{|c|c|c|c|c|c|c|}
\hline \multirow[t]{2}{*}{ Building } & \multicolumn{2}{|c|}{$\begin{array}{c}\text { Average Boiler On Cycle Count } \\
\text { per Year }\end{array}$} & \multicolumn{2}{|c|}{$\begin{array}{l}\text { Average Length of Boiler Cycle } \\
\text { (min) }\end{array}$} & \multicolumn{2}{|c|}{$\begin{array}{c}\text { Average } \% \text { of Time Boiler On } \\
\text { per Day } \\
\text { (per HDD) }\end{array}$} \\
\hline & Pre-Balancing & Post-Balancing & Pre-Balancing & Post-Balancing & Pre-Balancing & Post-Balancing \\
\hline 1 & 1265.4 & 1699.3 & 68.9 & 59.6 & 0.0098 & 0.0112 \\
\hline 2 & 1972.7 & 1030.1 & 68.9 & 75.3 & 0.0134 & 0.0085 \\
\hline 3 & 2015.1 & 1902.0 & 72.0 & 46.5 & 0.0137 & 0.0099 \\
\hline 4 & 1638.3 & 1142.9 & 52.6 & 61.5 & 0.0095 & 0.0078 \\
\hline 5 & 381.9 & 1509.7 & 163.3 & 44.1 & 0.0062 & 0.0074 \\
\hline 6 & 700.4 & 854.6 & 68.0 & 55.1 & 0.0052 & 0.0051 \\
\hline 7 & 540.5 & 885.0 & 143.5 & 64.5 & 0.008 & 0.0063 \\
\hline 8 & 1623.3 & 1458.5 & 78.6 & 78.1 & 0.0142 & 0.0124 \\
\hline 9 & 1615.6 & 1994.8 & 75.6 & 54.0 & 0.011 & 0.0118 \\
\hline 10 & $\begin{array}{c}\text { Data } \\
\text { unavailable }\end{array}$ & $\begin{array}{c}\text { Data } \\
\text { unavailable }\end{array}$ & $\begin{array}{c}\text { Data } \\
\text { unavailable }\end{array}$ & $\begin{array}{c}\text { Data } \\
\text { unavailable }\end{array}$ & $\begin{array}{c}\text { Data } \\
\text { unavailable }\end{array}$ & $\begin{array}{c}\text { Data } \\
\text { unavailable }\end{array}$ \\
\hline
\end{tabular}

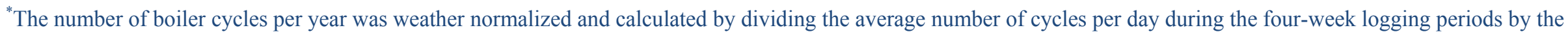
actual number of HDDs each day, then taking an average and extrapolating to a year's worth of cycles by multiplying by the (30-year average for the) total number of HDDs in a year. 
Using the weather-normalized average boiler on cycle count per year and the average length of boiler cycles, the number of hours that the boiler was on per year was calculated (Equation 1). A weather-normalized natural gas use was then calculated using the known input rating of the boiler (in kBtu/h) (Equation 2).

$$
D=C \times L
$$

$$
N=I \times D
$$

Where

$$
\begin{aligned}
& N=\text { weather }- \text { normalized natural gas used in a year }\left(\frac{k B t u}{y r}\right) \\
& I=\text { input rating of boiler }\left(\frac{k B t u}{h}\right) \\
& D=\text { weather }- \text { normalized time boiler on in a year }\left(\frac{h}{y r}\right) \\
& C=\text { weather }- \text { normalized average boiler on cycle count per year }\left(\frac{\text { cycles }}{y r}\right) \\
& L=\text { average length of boiler cycle }\left(\frac{h}{\text { cycle }}\right)
\end{aligned}
$$

The weather-normalized natural gas use $(N)$ of each boiler for the pre-measure and post-measure periods (in $\mathrm{kBtu} / \mathrm{yr}$ ) is depicted in Figure 13.

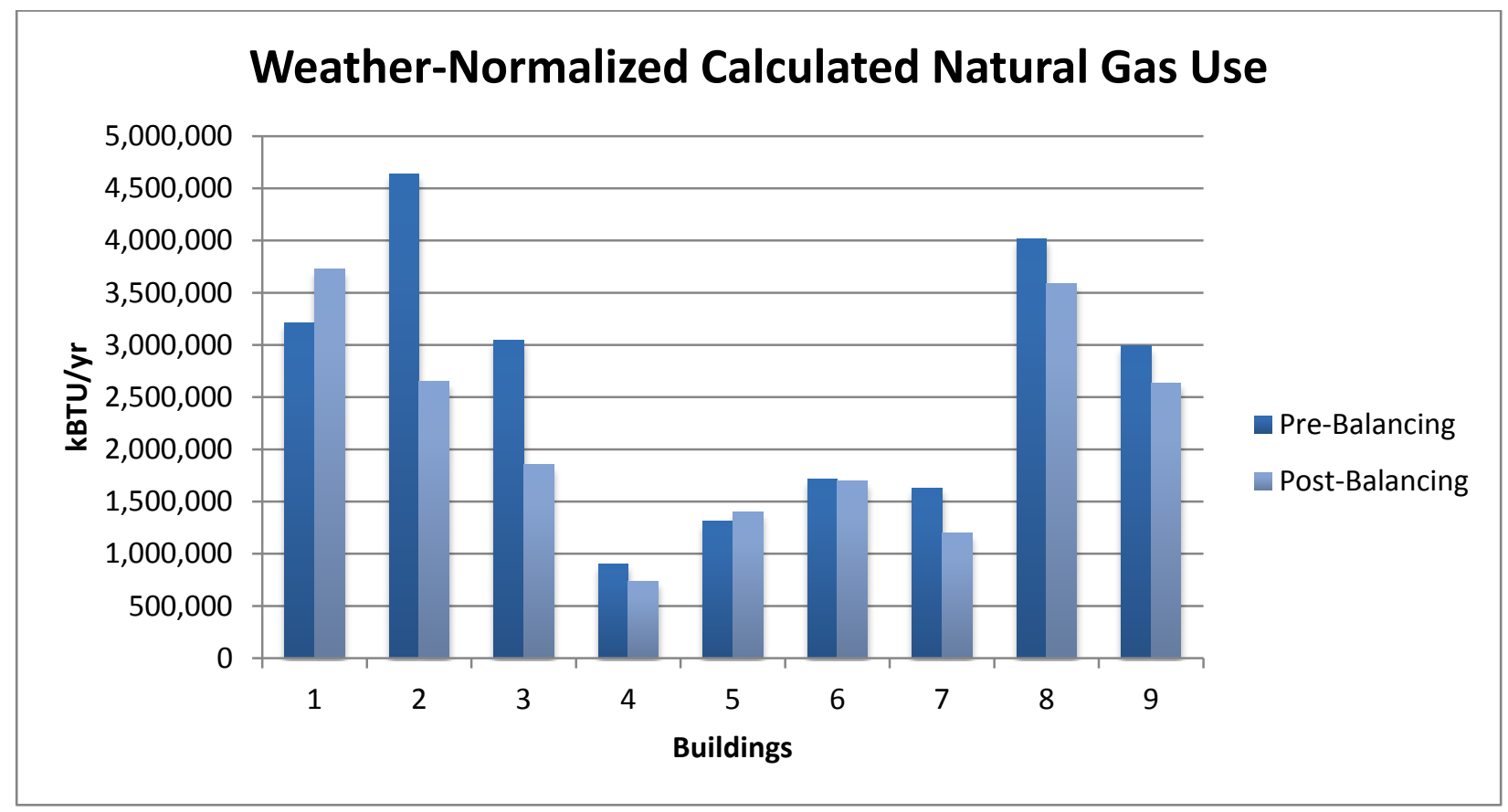

Figure 13. Weather-normalized calculated natural gas use pre-balancing and post-balancing

Seven of nine of the buildings were calculated to save natural gas on heating post-retrofit. 


\subsection{Cost Effectiveness}

This project focused on the cost effectiveness of steam balancing; thus, heavy analysis was conducted using measure costs and measured natural gas savings. The proposals for steam balancing from the contractor included itemized costs.

Natural gas savings were measured in two ways:

- A runtime logger was put directly onto the steam boiler to measure the length of the boiler cycles and to calculate how much gas the boiler was using before and after steam balancing. This gas use was normalized by HDD to determine weather-normalized natural gas savings.

- The pre-upgrade and post-upgrade energy use was compared via utility bill analysis.

Table 5 and Table 6 show data from both methods: the calculated natural gas use and the natural gas use from the energy use intensity (EUI) analysis. The EUI analysis, which uses actual billed natural gas use, was calculated and weather normalized for each building using CNT Energy's Standard Operating Procedure for energy use calculations. This value is shown for each building to show the validity of the calculated natural gas use (and therefore the predicted savings and cost effectiveness).

Table 5. Calculated Weather-Normalized Natural Gas Use

\begin{tabular}{c|c|c}
\hline \multirow{2}{*}{ Building } & \multicolumn{2}{|c}{$\begin{array}{c}\text { Calculated Natural Gas Use } \\
(\mathbf{k B t u} / \mathbf{y r})\end{array}$} \\
\cline { 2 - 3 } & Pre-Balancing & Post-Balancing \\
\hline $\mathbf{1}$ & $3,212,976$ & $3,727,292$ \\
\hline $\mathbf{2}$ & $4,641,805$ & $2,650,410$ \\
$\mathbf{3}$ & $3,045,649$ & $1,855,348$ \\
\hline $\mathbf{4}$ & 904,311 & 737,945 \\
\hline $\mathbf{5}$ & $1,309,707$ & $1,397,990$ \\
$\mathbf{6}$ & $1,717,699$ & $1,695,994$ \\
\hline $\mathbf{7}$ & $1,629,004$ & $1,198,514$ \\
$\mathbf{8}$ & $4,018,907$ & $3,589,474$ \\
\hline $\mathbf{9}$ & $2,990,757$ & $2,637,306$ \\
\hline $\mathbf{1 0}$ & Data unavailable & Data unavailable \\
\hline
\end{tabular}


Table 6. Measured Weather-Normalized Natural Gas Use

\begin{tabular}{c|c|c}
\hline \multirow{2}{*}{ Building } & \multicolumn{2}{|c}{$\begin{array}{c}\text { Natural Gas Use From EUI } \\
\text { (kBtu/yr) }\end{array}$} \\
\cline { 2 - 3 } & Pre-Balancing & Post-Balancing \\
\hline $\mathbf{1}$ & $2,765,951$ & Awaiting data \\
$\mathbf{2}$ & $3,511,732$ & Awaiting data \\
$\mathbf{3}$ & $1,334,622$ & Awaiting data \\
$\mathbf{5}$ & 731,978 & Awaiting data \\
$\mathbf{6}$ & $2,176,191$ & Awaiting data \\
$\mathbf{7}$ & $1,418,251$ & Awaiting data \\
\hline $\mathbf{8}$ & $1,375,888$ & Awaiting data \\
$\mathbf{9}$ & $2,165,435$ & Awaiting data \\
\hline $\mathbf{1 0}$ & $1,878,464$ & Awaiting data \\
\hline
\end{tabular}

The results of the second method of analysis will be included in a report as a part of a follow-up to this project, slated for completion in December 2012.

The total cost effectiveness of the steam balancing package tested (upgrading or replacing controls, installing main line vents, replacing radiator vents) was evaluated by calculating simple paybacks from projected yearly financial savings and measure costs. The average natural gas savings, measure costs, and simple payback are shown in Table 7.

Table 7. Average Percent Natural Gas Savings, Measure Costs, and Simple Payback

\begin{tabular}{c|c|c}
\hline $\begin{array}{c}\text { Natural Gas Savings } \\
(\%)\end{array}$ & $\begin{array}{c}\text { Measure Costs } \\
(\mathbf{\$})\end{array}$ & $\begin{array}{c}\text { Simple Payback } \\
\text { (yrs) }\end{array}$ \\
\hline 14.2 & 9,434 & 21.3 \\
\hline
\end{tabular}

${ }^{* *}$ The percent natural gas savings shown here is for heating load only.

${ }^{* * *}$ The simple payback was calculated using an estimate of $\$ 1 /$ therm natural gas.

Long-term monitoring of building performance would be an interesting study to examine whether a building owner would see sustained savings from steam balancing measures. This would be accomplished by applying the standard utility bill analysis employed by CNT Energy for at least two years following construction.

\subsection{Tenant Comfort}

Tenants of the units where loggers were placed were surveyed about their temperature comfort and whether they opened their windows or used additional heat sources during the heating season before and after the retrofits were done. (A sample survey is provided in Appendix C.) The 
response rate was $44 \%$ pre-retrofit and $56 \%$ post-retrofit (this translates to an average response rate of $12 \%$ of an entire building's tenants pre-retrofit and $17 \%$ post-retrofit).

Figure 14 shows the average survey responses when tenants were asked to rate their overall temperature comfort on a scale from $1=$ Uncomfortable to $5=$ Comfortable. All the buildings except Buildings 1 and 6 saw improvements in rated comfort post-retrofit.

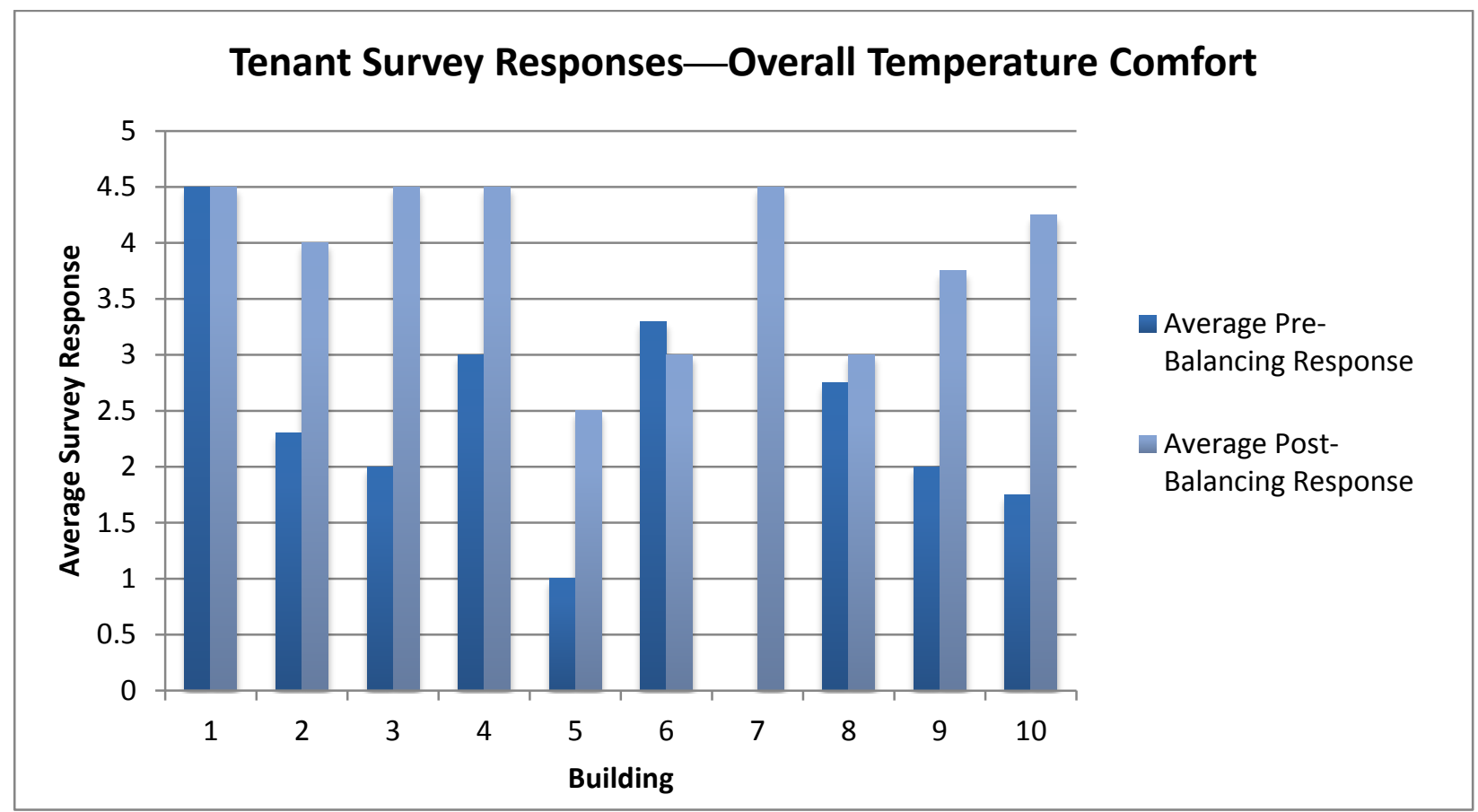

Figure 14. Tenant survey responses rating overall temperature comfort. The tenants were asked to rate the overall temperature comfort within their unit on a scale from $1=$ Uncomfortable to $5=$ Comfortable. Note: Building 7 received no survey responses pre-retrofit. 


\section{Results and Discussion}

\subsection{Temperature Control and Steam Systems Behavior}

Each test building responded differently to the steam balancing measures. Their pre-measure conditions were drastically different, so this was expected. However, some of the differences in the pre-measure and post-measure temperature data were:

- Changes in the diurnal temperature patterns within units (different schedules of when the units were warmest and when they were coolest)

- Smaller temperature differentials between the hottest and coldest units.

The changes in heating schedules (highlighted in Building 5) should provide heat at appropriate times and increase resident comfort. Because this change was determined primarily by the type of controls in place, newly installed boiler controls seem to have contributed significantly to more comfortable temperature settings. The indoor averaging system and the more advanced temperature set point control (allowing for nighttime, daytime, and differential set points) seem to have more tightly regulated the heating schedules.

A decrease in the temperature differential between the hottest and coldest units was also seen in some buildings. This suggests that heat was being more evenly distributed, reaching units that previously received less heat. This could have been because the indoor averaging temperature controls regulated the boiler to stay on longer, until heat reached the further units, or because the increased venting allowed steam to travel faster through the mains and to the radiators. Buildings 2 and 4 showed an increase in their average boiler cycle lengths, suggesting that longer cycles were needed for heat to reach the further tiers in the buildings. This evener heat distribution is also expected to increase resident comfort.

The balancing work had varying effects on the lengths and frequency of boiler cycles (shown in Table 4). Some buildings saw shorter cycles post-retrofit and some saw much longer cycles. Some saw more boiler cycles and some saw fewer. As previously stated, this was expected because each building had unique pre-retrofit conditions. This suggests that it is difficult to predict exactly how the balancing work, especially the increased or upgraded venting, will change temperature dynamics and boiler behavior. What is evident, however, is that several trips and adjustments are often needed after the initial round of balancing work is done. Building 3 (see Figure 15 and Figure 16) showed an example of a building where the midrange temperature units were more uniformly heated to a comfortable temperature, but the outliers remained after the balancing work was done. The building had shorter and fewer boiler cycles post-retrofit, meaning that it was saving natural gas and money, but issues with controlling the heat to the hottest and coldest units need to be investigated and addressed further. 


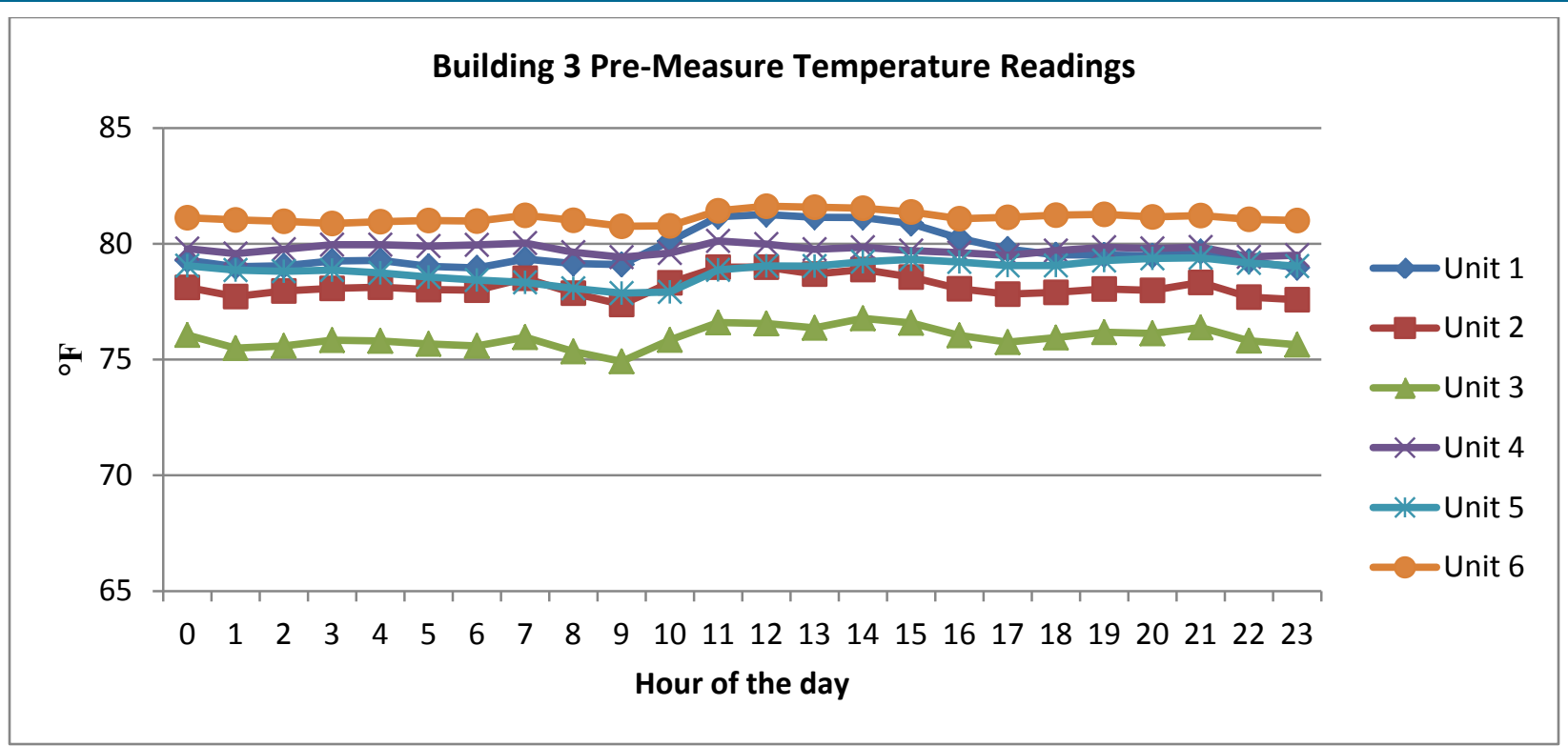

Figure 15. Building 3 average pre-measure logging period temperature readings by hour of the day

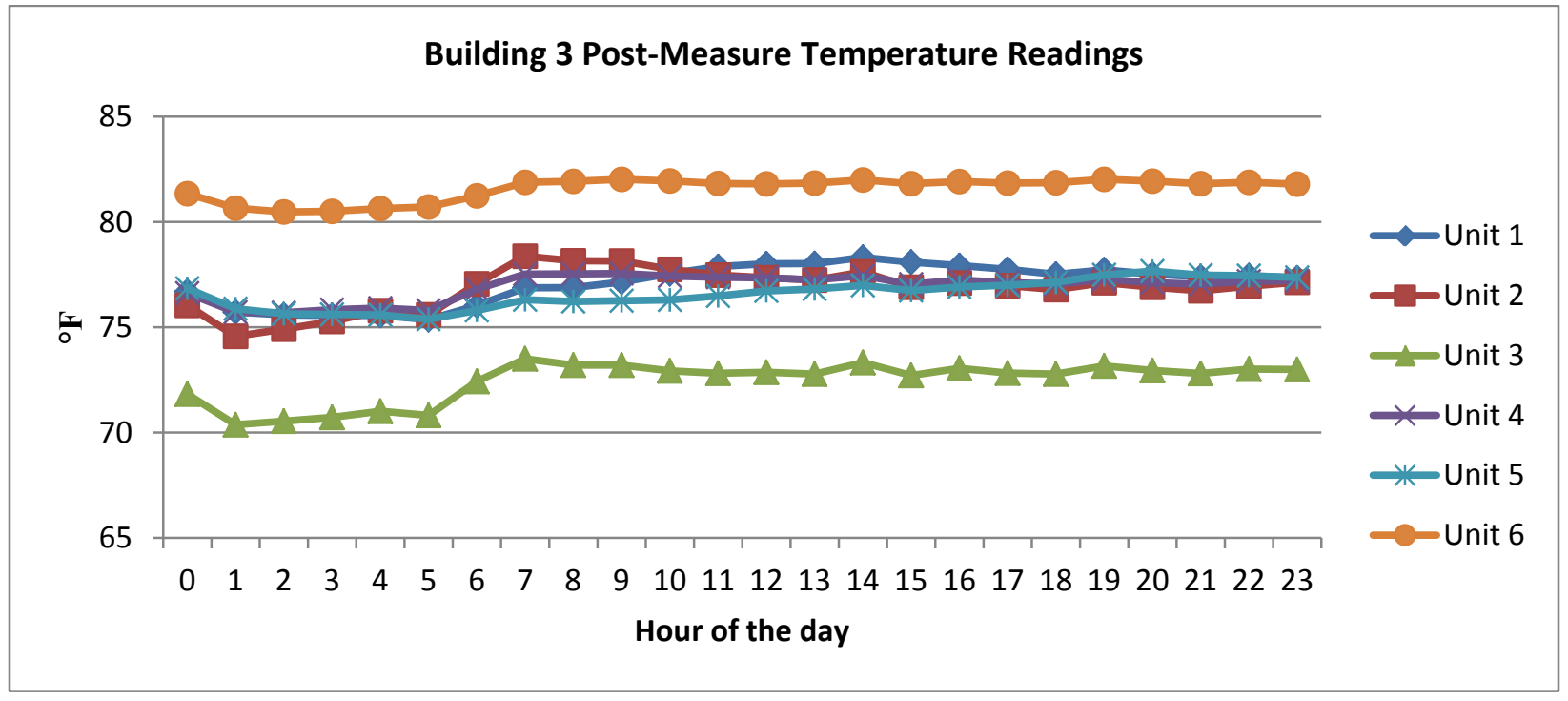

Figure 16. Building 3 average post-measure logging period temperature readings by hour of the day

\subsection{Cost Effectiveness}

The natural gas used for heating before and after the balancing work was first calculated by using the data collected from the boiler runtime data logger. These calculations showed that all except two of the test buildings (Buildings 1 and 5), were using less natural gas after the retrofits were completed. It was commonly found that before the steam balancing was done, owners were overheating their buildings to compensate for units that were not receiving heat quickly enough. By distributing heat more evenly and allowing steam to be more quickly delivered to units 
(rather than being dissipated in the basement because of insufficient main line venting), the balancing work is theoretically saving natural gas and money. It was calculated that the test buildings will save $1.3 \%-43 \%$ of their heating load natural gas use (about $14.2 \%$ on average). The payback period for the steam balancing measures (shown in Table 6) was 21.3 years for the test buildings. This is higher than previous studies and research have shown, likely because the measures and contractor work were extremely extensive and controlled for the sake of the study. The costs of the radiator vent replacements, for example, were likely higher than average because the vents were all replaced by the contractor and therefore included high labor costs. In a standard balancing project that is less strictly controlled, the payback period would likely be much shorter. The simple payback shown here also does not take into account fluctuations in fuel costs. With expected fuel cost increases, the payback period would likely be decreased even further. The benefit of tenant comfort (which would begin immediately after a building is properly balanced) should also be considered as an important added value.

The natural gas savings will also be confirmed by looking at the actual heating bills for the buildings. The pre-retrofit natural gas use (shown in Table 5) mostly seemed to be overestimated when calculated using the boiler input, probably because the boiler may not have always used its maximum, steady-state input (used in the calculated values) each time it cycled on. However, this overestimate was a fairly consistent percentage across all the buildings, so the calculated value appears to provide an informative estimate of the gas use and savings.

\subsection{Tenant Perceptions}

Records of tenant complaints about the heat should be used in conjunction with logger data when determining how to balance a building. These often indicate where heat is not reaching.

Building owners often stopped overheating their buildings because of the new controls or adjusted venting, so major heating imbalances became more obvious. The units that received heat more slowly may have initially received even less heat after the temperature set points were turned down or adjusted, so tenants were more likely to notice heating deficiencies caused by imbalances. Also, many tenants were used to having their units overheated (often up to $80^{\circ}-$ $85^{\circ} \mathrm{F}$ ), so they were more likely to complain once set points were adjusted properly and they were receiving less heat than before. The two buildings that showed a lower average rated temperature comfort were likely either experiencing this phenomenon post-retrofit, or they were still being overheated. Though the venting was adjusted, these buildings may require more follow-up visits to further assess the distribution systems. 


\section{Conclusions and Recommendations}

\subsection{Establishing Steam Balancing Guidelines}

Several additional points are important to consider when deciding to balance a building:

- Balancing is a multistage process. All the information in the Experiment section should first be collected on a building thought to need balancing. Once a building has initially had the steam balancing measure package installed, the effectiveness of the retrofits should be assessed based on conversations with the building manager and tenants and on temperature data. The building may need to be rebalanced, reassessed, and perhaps further adjusted.

- Unit locations and building layout are important to consider when assessing and balancing a building. Each building will have different hot and cold spots and will require different venting configurations and placement of control sensors.

- Tenants and building managers need to be informed about the balancing process and that its success will require time and cooperation. The balancing work will be most effective when tenants and building managers cooperate. For example, tenants should be informed that using space heaters drives up the temperature that the indoor averaging system uses to control the boiler. This means that the boiler will not come on in a building even if some units are substantially below the set point and the temperature monitoring will be inaccurate. Building managers should be properly instructed about how to use the newly installed controls and tenants should be informed that the work will require their cooperation and occasional access to their units.

\subsection{Further Recommended Studies}

Though the results of this project are generally positive, further studies should be done to more conclusively determine the effects of steam balancing. Variables were monitored as closely as possible, but the test buildings were occupied and thus subject to unpredictable tenant behavior. This caused uncertainties in some temperature measurements collected. More controlled studies could be done to conclusively determine the effect of balancing on temperature dynamics within units.

The effectiveness of the three separate measures considered as a package in this project could be examined by installing them individually and assessing the temperature distributions and natural gas uses in a new set of test buildings. Measures such as thermostatic radiator valves could also be evaluated.

Taking temperature readings at one-minute intervals would also help shed light on how the balancing work affects the time to heat a unit. The higher resolution data could be matched with the boiler runtime data to see how long it takes to heat a unit after a boiler cycles on. This would require either remotely monitored data loggers or entering into units more frequently to collect more data. This would also require more stringent cooperation from tenants. 
Longer term monitoring would also further inform the cost effectiveness of steam balancing. This is currently being planned as a Building America study to be conducted by CNT Energy in collaboration with GTI as a follow-up to this project. 


\section{References}

Biederman, N.; Katrakis, J. (1986). Space Heating Efficiency Improvements in Multifamily Buildings. GRI 88/0111. Chicago: Gas Research Institute. www.gastechnology.org/.

DOE. (2011.) Building America: Program Goals. Washington, D.C.: U.S. Department of Energy. http://www1.eere.energy.gov/buildings/building_america/program goals.html.

Evens, A.; Ludwig, P.; Kotewa, L. (2008). “Cook County Energy Savers: How Energy Efficiency in Chicago's Multi-Family Buildings Has Evolved to Meet New Challenges from the 1980's to the Present Day." ACEEE Summer Study on Energy Efficiency in Buildings. 2-197.

Gorton Heating Corporation. (2006). Gorton Heating. www.gorton-valves.com.

Holohan, D. (1996). A Pocketful of Steam Problems. D. Holohan Associates.

Holohan, D. (2010). Greening Steam How to Bring $19^{\text {th }}$-Century Heating Systems into the $21^{\text {st }}$ Century (and save lots of green!). Daniel Holohan Associates, Inc.

Holohan, D. (2010). Balancing One Pipe Steam Systems. www.heatinghelp.com/article/11/HotTech-Tips/138/Balancing-One-Pipe-Steam-Systems.

Katrakis, J.; Zawacki, T. (1993). "Field Measured Seasonal Efficiency of Intermediate-Sized Low Pressure Steam Boilers." ASHRAE Transactions. www.ashrae.org.

Katrakis, J.; Lobenstein, M.; Hewett, M. (2010). “Cost-Effective Boiler System Retrofits.” Consulting-Specifying Engineer. http://m.csemag.com/index.php? $\mathrm{id}=2832 \& t x$ ttnews[tt_news] $=22127 \& \mathrm{cHash}=3 \mathrm{~b} 07 \mathrm{e} 71 \mathrm{e} 00$.

Peerless Boilers. (1996). Series 211A - Gas Boilers - Steam - Installation, Operation \& Maintenance Manual. Bally, PA: PB Heat, LLC.

Peterson, G. (1985). Achieving Even Space Heating in Single Pipe Steam Buildings. CEE TR858-MF. Minneapolis: Center for Energy and Environment. www.mncee.org/.

Peterson, G. (1986). Multifamily Pilot Project: Single Pipe Steam Balancing \& Hot Water Outdoor Reset. Minneapolis Energy Office. www.mncee.org/pdf/tech_pubs/86-5.pdf.

Peterson, G.; Otterson, S. (1985). Single Pipe Steam Air Venting. CEE TR85-3-MF. Minneapolis: Center for Energy \& Environment. www.mncee.org/. 


\section{Appendix A. Test Building Details}

\begin{tabular}{|c|c|c|c|c|}
\hline \multirow[t]{2}{*}{ Building } & \multirow[t]{2}{*}{ Type } & \multirow[t]{2}{*}{ \# Units } & \multicolumn{2}{|c|}{$\begin{array}{l}\text { Natural Gas Heating Load EUI } \\
\left(\mathbf{k B t u} / \mathrm{ft}^{2} / \mathrm{yr}\right)\end{array}$} \\
\hline & & & Pre-Balancing & Post-Balancing \\
\hline 1 & $\begin{array}{l}\text { 3-story brick courtyard } \\
\text { building, flat roof }\end{array}$ & 33 & 112 & Awaiting data \\
\hline 2 & $\begin{array}{l}\text { 3-story brick courtyard } \\
\text { building, flat roof }\end{array}$ & 30 & 121 & Awaiting data \\
\hline 3 & $\begin{array}{l}\text { 3-story brick courtyard } \\
\text { building, flat roof }\end{array}$ & 16 & 77 & Awaiting data \\
\hline 4 & $\begin{array}{l}\text { 3-story brick walk-up, } \\
\text { flat roof }\end{array}$ & $\begin{array}{l}6 \text {, converted } \\
\text { to } 20\end{array}$ & 85 & Awaiting data \\
\hline 5 & $\begin{array}{l}\text { 3-story brick courtyard } \\
\text { building, flat roof }\end{array}$ & 15 & 163 & Awaiting data \\
\hline 6 & $\begin{array}{l}\text { 3-story brick walk-up, } \\
\text { flat roof }\end{array}$ & 18 & 90 & Awaiting data \\
\hline 7 & $\begin{array}{l}\text { 3-story brick courtyard } \\
\text { building, flat roof }\end{array}$ & 16 & 119 & Awaiting data \\
\hline 8 & $\begin{array}{l}\text { 3-story brick courtyard } \\
\text { building, flat roof }\end{array}$ & 24 & 122 & Awaiting data \\
\hline 9 & $\begin{array}{l}\text { 3-story brick walk-up, } \\
\text { flat roof }\end{array}$ & 21 & 116 & Awaiting data \\
\hline 10 & $\begin{array}{l}\text { 3-story brick walk-up, } \\
\text { flat roof }\end{array}$ & 32 & 91 & Awaiting data \\
\hline
\end{tabular}

*The post balancing EUI will be found as a part of the follow-up project discussed in the Further Recommended Studies section. 
Pre-Balancing Natural Gas Use (for Heating) in Test Buildings

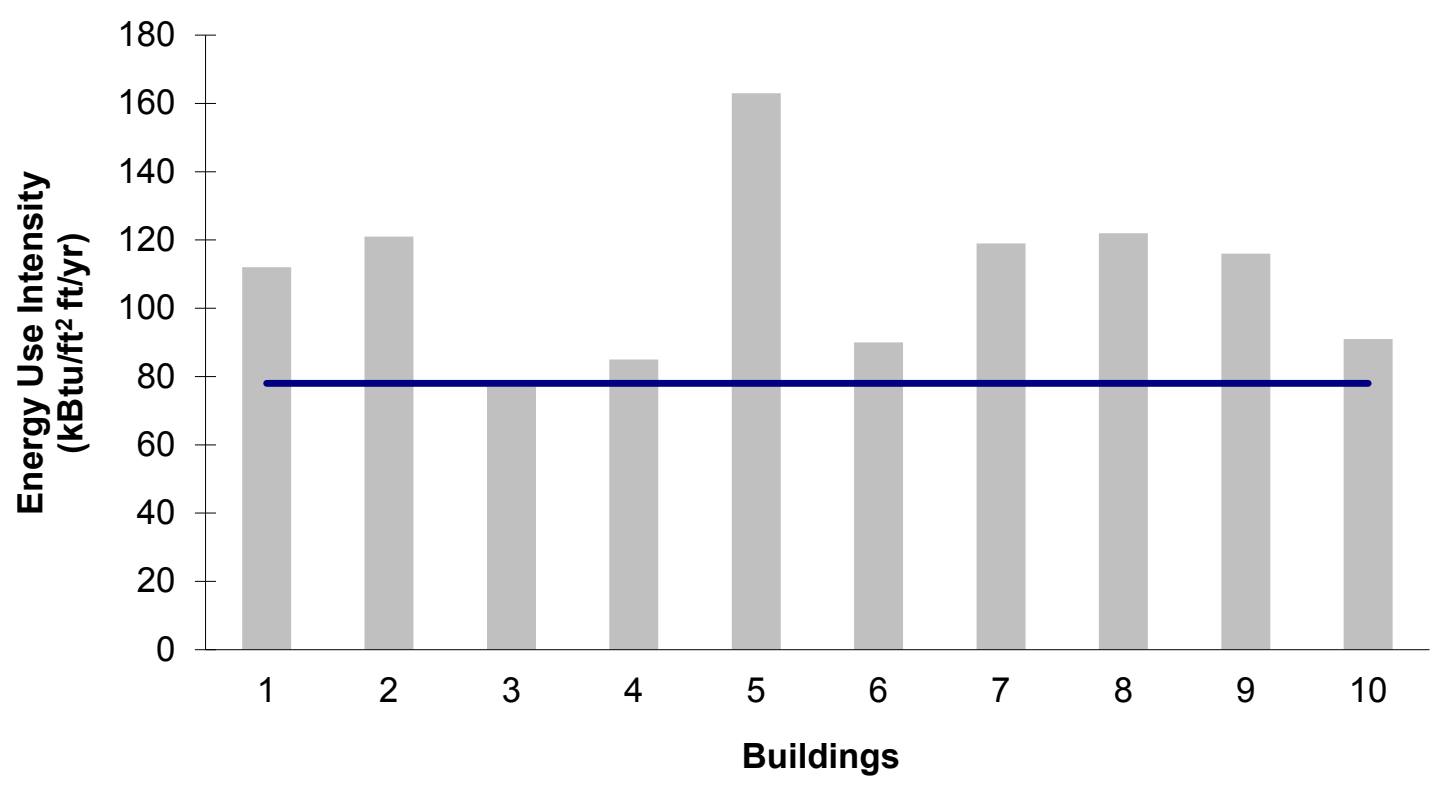

Figure A-1. The pre-measure heating EUI for each test building is at or above the line representing the median EUI for 105 similar steam-heated buildings in Chicago. This suggests that the buildings chosen for this study all had potential for energy savings. 


\section{Appendix B. Sample Tenant Letter}

Dear Tenant,

On 2011, we installed a temperature data logger in your apartment unit. We are working with your landlord to find and address any heating issues within the building; this data logger provides information for that work.

We ask that you do not remove or disturb the logger. It will allow us to collect useful information that should improve your comfort during the heating season.

We will need to access your apartment again in about $\mathbf{4}$ weeks to collect the temperature data and reset the data logger. You will be notified again by your landlord prior to our next visit.

We very much appreciate your cooperation. If you have any questions, please contact your landlord or building manager.

Sincerely,

The Energy Savers Team

CNT Energy

$<$ Phone Number> 


\section{Appendix C. Sample Tenant Survey}

Pre-Measure Occupant Comfort Survey-Steam Balancing and Tuning

Address:

Date:

Unit:

How long have you lived in the unit?

Overall temperature comfort:

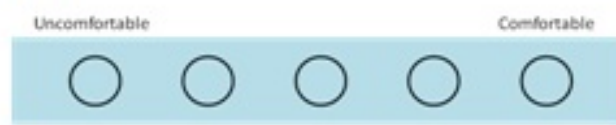

How cold it gets:

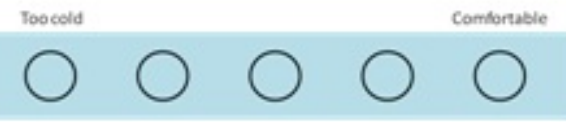

How warm it gets:

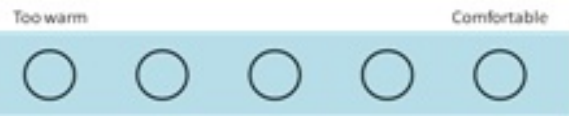

Temperature shifts:

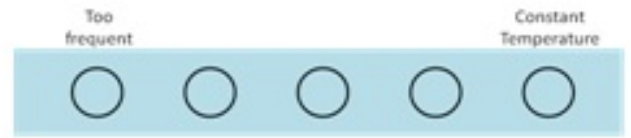

Your ability to adjust the room temperature:

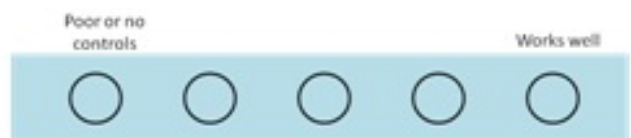

Do you use the oven or space heaters to additionally heat your apartment?

Do you ever open your windows to cool down your apartment during the heating season?

Other comments about the heat: 


\section{Appendix D. Detailed Measures and Costs}

\begin{tabular}{|c|c|c|c|}
\hline Building & Measures Completed & $\begin{array}{l}\text { Individual } \\
\text { Measure } \\
\text { Costs } \\
(\$)\end{array}$ & $\begin{array}{l}\text { Total } \\
\text { Cost } \\
(\$)\end{array}$ \\
\hline 1 & $\begin{array}{l}\text { Main line vents } \\
\text { Radiator vents } \\
\text { Boiler controls (RD AH207 - } 6 \text { indoor sensors, } 1 \text { outdoor sensor) }\end{array}$ & $\begin{array}{l}4,695 \\
5,842 \\
6,955\end{array}$ & 17,532 \\
\hline 2 & $\begin{array}{l}\text { Main line vents } \\
\text { Radiator vents } \\
\text { Boiler controls (RD AH207 - } 6 \text { indoor sensors, } 1 \text { outdoor sensor) }\end{array}$ & $\begin{array}{l}1,560 \\
5,200 \\
6,995\end{array}$ & 13,755 \\
\hline 3 & $\begin{array}{l}\text { Main line vents } \\
\text { Radiator vents } \\
\text { Boiler controls (RD 1404T }-4 \text { indoor sensors, } 1 \text { outdoor sensor) }\end{array}$ & $\begin{array}{l}1,540 \\
2,820 \\
4,500\end{array}$ & 8,860 \\
\hline 4 & $\begin{array}{l}\text { Main line vents } \\
\text { Radiator vents } \\
\text { Boiler controls (RD 1404T }-4 \text { indoor sensors, } 1 \text { outdoor sensor) }\end{array}$ & $\begin{array}{l}895 \\
2,195 \\
4,698\end{array}$ & 7,788 \\
\hline 5 & $\begin{array}{l}\text { Main line vents } \\
\text { Radiator vents } \\
\text { Boiler controls (RD RF207 - } 6 \text { indoor sensors, } 1 \text { outdoor sensor) }\end{array}$ & $\begin{array}{l}1,295 \\
2,295 \\
3,900\end{array}$ & 7,490 \\
\hline 6 & $\begin{array}{c}\text { Main line vents } \\
\text { Radiator vents } \\
\text { Boiler controls (RD 1206-6 indoor sensors, } 1 \text { outdoor sensor) }\end{array}$ & $\begin{array}{c}1,570 \\
5,500 \\
4,500(\text { est })^{*}\end{array}$ & 11,570 \\
\hline 7 & $\begin{array}{l}\text { Main line vents } \\
\text { Radiator vents } \\
\text { Boiler controls (RD RF207 - } 6 \text { indoor sensors, } 1 \text { outdoor sensor) }\end{array}$ & $\begin{array}{l}1,495 \\
2,395 \\
3,900\end{array}$ & 7,790 \\
\hline 8 & $\begin{array}{l}\text { Main line vents } \\
\text { Radiator vents } \\
\text { Boiler controls (RD } 1204-4 \text { indoor sensors, } 1 \text { outdoor sensor) }\end{array}$ & $\begin{array}{l}1,798 \\
3,589 \\
4,000\end{array}$ & 9,387 \\
\hline 9 & $\begin{array}{l}\text { Main line vents } \\
\text { Radiator vents } \\
\text { Boiler controls (RD 1404T }-4 \text { indoor sensors, } 1 \text { outdoor sensor) }\end{array}$ & $\begin{array}{l}1,500 \\
3,295 \\
4,500\end{array}$ & 9,295 \\
\hline 10 & $\begin{array}{l}\text { Main line vents } \\
\text { Radiator vents } \\
\text { Boiler controls (RD 1206 - } 6 \text { indoor sensors, } 1 \text { outdoor sensor) }\end{array}$ & $\begin{array}{c}1,678 \\
3,695 \\
4,000 \text { (est)* }\end{array}$ & 9,373 \\
\hline
\end{tabular}

*The boiler control costs for Buildings 6 and 10 are estimated costs because the owner had installed these prior to the start of the project and CNT Energy did not receive the formal proposals for these installations. The buildings were run on their original timers/thermostats during the prelogging period to simulate "pre" boiler control conditions. 


\section{U.S. DEPARTMENT OF Energy Efficiency \& ENERCY Renewable Energy}

